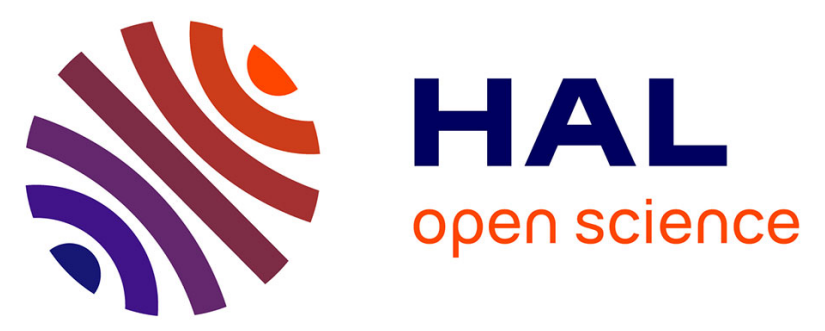

\title{
Evaluation of morphometric proxies for uplift on sequences of coral reef terraces: A case study from Sumba Island (Indonesia)
}

Maëlle Nexer, Christine Authemayou, Taylor Schildgen, Wahyoe S. Hantoro, Stéphane Molliex, Bernard Delcaillau, Kevin Pedoja, Laurent Husson, Vincent Regard

\section{To cite this version:}

Maëlle Nexer, Christine Authemayou, Taylor Schildgen, Wahyoe S. Hantoro, Stéphane Molliex, et al.. Evaluation of morphometric proxies for uplift on sequences of coral reef terraces: A case study from Sumba Island (Indonesia). Geomorphology, 2015, 241, pp.145-159. 10.1016/j.geomorph.2015.03.036 . insu-01164282

\section{HAL Id: insu-01164282 https://hal-insu.archives-ouvertes.fr/insu-01164282}

Submitted on 9 Jul 2021

HAL is a multi-disciplinary open access archive for the deposit and dissemination of scientific research documents, whether they are published or not. The documents may come from teaching and research institutions in France or abroad, or from public or private research centers.
L'archive ouverte pluridisciplinaire HAL, est destinée au dépôt et à la diffusion de documents scientifiques de niveau recherche, publiés ou non, émanant des établissements d'enseignement et de recherche français ou étrangers, des laboratoires publics ou privés. 


\section{Evaluation of morphometric proxies for uplift on sequences of coral reef terraces: A case of study from Sumba Island (Indonesia)}

Maëlle Nexer ${ }^{1,2,3, *}$, Christine Authemayou ${ }^{4}$, Taylor Schildgen ${ }^{5}$, Wahyoe S Hantoro ${ }^{6}$, Stéphane

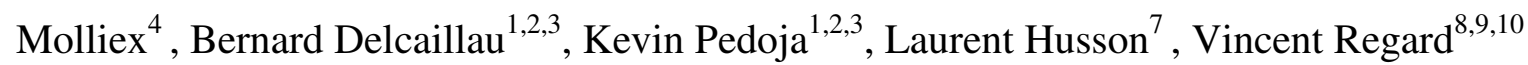

${ }^{1}$ Normandie Univ, Laboratoire M2C, 24 Rue des Tilleuls, 14000 Caen, France.

${ }^{2}$ UCBN, M2C, F-14000 Caen, France.

${ }^{3}$ CNRS, UMR 6143 M2C, F-14000 Caen, France.

${ }^{4}$ Laboratoire Domaines Océaniques UMR CNRS 6538, Institut Universitaire Européen de la Mer, Université de Bretagne Occidentale, place N. Copernic F-29280 Plouzané, France.

${ }^{5}$ University of Potsdam, Department of Earth and Environmental Science, 14476 Potsdam, Germany.

${ }^{6}$ Research Center for Geotechnology, Indonesian Institut of Sciences, Komplek LIPI Gd 70, J1 Sangkuriang Bandung 40135 Indonesia.

${ }^{7}$ ISTerre, CNRS UMR 5275, Univ. Grenoble Alpes, F-38041 Grenoble, France.

${ }^{8}$ Université de Toulouse, UPS (OMP).

${ }^{9}$ GET ; 14 Av Edouard Belin, F-31400 Toulouse, France.

${ }^{10}$ IRD ; GET ; F-31400 Toulouse, France.

*Corresponding author.Tel: +332315657 16,E-mail address: maelle.nexer@unicaen.fr

Keywords: Drainage morphometry, coral reef terraces, uplift, Pleistocene, Sumba Island, Indonesia

\section{Abstract}


Sequences of coral reef terraces characterized by staircase morphologies and a homogeneous lithology make them appropriate to isolate the influence of uplift on drainage morphology. Along the northern coast of Sumba Island, Indonesia, we investigated the correlations between landscape morphology and uplift rates, which range from 0.02 to $0.6 \mathrm{~mm} \cdot \mathrm{yr}^{-1}$. We studied eight morphometric indices at two scales: whole island $\left(\sim 11000 \mathrm{~km}^{2}\right)$ and within sequences of reefal terraces $\left(\sim 3000 \mathrm{~km}^{2}\right)$. At the latter scale, we extracted morphometric indices for 15 individual catchments draining mostly the reefal terraces and for 30 areas undergoing specific ranges of uplift rates draining only the reefal terraces. Indices extracted from digital elevation models include residual relief, incision, stream gradient indices (SL and $k_{\mathrm{sn}}$ ), the hypsometric integral, drainage area, mean relief, and the shape factor. We find that $S L$, the hypsometric integral, mean relief and the shape factor of catchments positively correlate with uplift rates, whereas incision, residual relief, and $k_{\mathrm{sn}}$ do not. More precisely, we find that only the areas that are uplifting at a rate faster than $0.3 \mathrm{~mm}_{\mathrm{yr}} \mathrm{yr}^{-1}$ can yield the extreme values for these indices, implying that theses extreme values are indicative of fast uplifting areas. However, the relationship is not bivalent because any uplift rate can be associated with low values of the same indices. For all indices, the transient conditions of the drainage influence the correlation with Pleistocene mean uplift rates, illustrating the necessity to extract morphometric indices with an appropriate choice of catchment scale. This type of analysis helps to identify the morphometric indices that are most useful for tectonic analysis in areas of unknown uplift, allowing for easy identification of short spatial variations of uplift rate and detection of areas with relatively fast uplift rates in unstudied coastal zones.

\section{Introduction}


Rates and patterns of vertical ground motions constitute a basic framework for understanding the kinematics of deforming lithosphere. Their quantification requires identifying displaced geomorphic markers such as strandlines (i.e. marine terraces including coral reef terraces) stacked in sequences (e.g. Lyell, 1851; Pedoja et al., 2011, 2014) or fluvial terraces (e.g. Burbank et al., 1996). Calibrating morphometric indices with landscape maturity and tectonic deformation requires comparisons with regions of known uplift history. The ability to derive uplift histories from marine or reefal terrace analysis in coastal zones therefore makes such settings ideal for testing and further developing morpho-tectonic analysis techniques. Nonetheless, studies focused on drainages developed on Pleistocene marine or coral reef terraces are relatively scarce. Besides Chappell's (1974a) study of coral reef sequences, many studies are based on erosional marine terraces. Several of these studies analyze the variations of morphometric indices of catchments as a function of local coastal uplift rate derived from the analysis of uplifted marine terraces (Merrits and Vincent, 1989; Snyder et al., 2000; Duvall et al., 2004; Perron and Royden, 2012). Most have focused on California (USA), where uplift rates are moderate to high ( $\geq 0.5 \mathrm{~mm} . \mathrm{yr}^{-1}$ according to Snyder et al. 2000).

To explore the relationships between uplift rates and landscape morphology, we studied a 300-km-long coastal stretch on the northern coast of Sumba Island, Indonesia (Fig. 1), affected by slow to moderate uplift rates varying from $\sim 0.02$ to $\sim 0.6 \mathrm{~mm} . \mathrm{yr}^{-1}$. We focused on the drainage networks that are developed on the sequences of coral reef terraces. We exploited the systematic spatial variation in rock uplift rates recorded in the terrace sequences of Sumba Island to assess the manner and degree to which morphometric indices can be correlated with tectonic forcing. The uniform climate and lithology across the study area (most bedrock is composed of Quaternary reefal limestones) allow us to isolate the influence of uplift on coastal streams and catchments. The well-established chronostratigraphy of the coral reef 
terrace sequence found at Cape Laundi (30-km-long coastal fringe; Fig. 1; Pirazzoli et al., 1991; Hantoro, 1992; Pirazzoli et al. 1993; Bard et al., 1996), combined with the lateral continuity of some of the terraces, allows us to extrapolate uplift rates throughout the entire coastal stretch covered by reefal terraces $(\sim 350 \mathrm{~km})$. Because coastal sequences are ubiquitous markers worldwide (Pedoja et al., 2011, 2014), our aim is to identify the morphometric indices that can be used as widely applicable reconnaissance tools to detect variations in uplift rates. Our results suggest that this procedure may be applied to identify rapidly uplifting areas along any given coastal area that includes a sequence of reefal or marine terraces.

\section{$2 \quad$ Setting}

Sumba Island is $200 \mathrm{~km}$ wide and $650 \mathrm{~km}$ long. It separates the Savu forearc basin (Savu Sea) to the east from the Lombok fore-arc basin to the west, and is bordered by the Indian Ocean to the south (Harris et al., 2009; Harris, 2011). The width of the shelf surrounding Sumba Island is relatively narrow, ranging from 0.6 to $16 \mathrm{~km}$ (Fig. 2), which corresponds to a slope gradient from 0.006 to 0.2 . The $120 \mathrm{~m}$ isobath corresponds to the mean location of sea level during the Last Glacial Maximum (e.g. Lambeck et al., 2002) and allows us to highlight the shelf extent during that time (Fig. 2).

Sumba Island is located at the junction between the Indian-Australian and Eurasian plates (Hall, 2002), lying between an oceanic subduction (the Java trench) to the west and an arccontinent collision zone to the east (Fig. 1; Harris et al., 2009; Harris, 2011). West of Sumba, the Indian-Australian oceanic plate subducts northward beneath the Eurasian plate (i.e., the Sunda shelf) at a speed of $75 \mathrm{~mm} . \mathrm{yr}^{-1}$ according to GPS data (e.g. Hinschberger et al., 2005). This speed has been relatively constant for the last $\sim 45 \mathrm{Ma}$ (Hall, 2002). East of Sumba, the Australian plate collides obliquely with the Sunda-Banda arc along the Timor trench 
(Hinschberger et al., 2005; Shulgin et al., 2009). The collision between the Banda arc and the Australian margin started around $6 \mathrm{Ma}$ in the Timor region (Haig, 2012) rather than during the Pliocene or Pleistocene as some authors have suggested (Hall and Smyth, 2008; Keep and Haig, 2010; Audley-Charles, 2011). The collision later impacted the Sumba ridge at around 3 Ma (Fortuin et al., 1997; Harris, 2011). This collision is interpreted as the cause of the general uplift and the numerous faults observed on Sumba Island (Fleury et al., 2009). Sumba Island has been alternatively interpreted as (1) an island-arc built on the ocean floor (Lytwyn et al., 2001; Abdullah et al., 2000), or (2) a fragment of continental crust either lying on the Australian continental shelf (Audley-Charles, 1975; Hinschberger et al., 2005) or originating from the Eurasian plate (Rutherford et al., 2001; Hall and Sevastjanova, 2012).

The Late Cretaceous to Quaternary deposits preserved on Sumba Island (Fig. 2) record volcanism, margin sedimentation, and a general regression associated with the uplift of the island (Abdullah et al., 2000; Fig. 2). The volcanic rocks are Late Cretaceous (Masu Formation) and Eocene-Oligocene (Jawila Formation) in age. The sedimentary cover is composed of three units: the Waikabubak limestones (Mio-Pliocene), the Kannanggar limestones and turbiditic sandstones (Mio-Pliocene), and the Quaternary reefal limestones (Rutherford at al. 2001; Fig. 2). All these units have been recently affected by normal faults associated with the gravitational collapse of the southern part of the island (Fleury et al., 2009).

Sequences of coral reef terraces are well represented on Cape Laundi (Jouannic et al. 1988; Pirazzoli et al., 1991; Hantoro, 1992; Pirazzoli et al. 1993; Bard et al., 1996; Rutherford et al., 2001) and are preserved along approximately $2 / 3$ of the coast of the island (Fleury et al., 2009). Reefal terraces have been studied carefully only in the vicinity of Cape Laundi, where seven main coral reef terraces rising up to $450 \mathrm{~m}$ in elevation have been described (Jouannic 
et al. 1988; Pirazzoli et al. 1991, 1993; Hantoro, 1992; Bard et al. 1996; Fleury et al., 2009), numbered from 0 to VI in Fig. 3. Based on U/Th dating of corals sampled from the lowstanding terraces ( 0 to IVa), previous studies correlated the whole sequence to highstands ranging from Holocene (reef crest 0) to MIS 29 (reef crest VI, 1 Ma) (Fig. 3; Jouannic et al., 1988; Pirazzoli et al., 1991, 1993; Hantoro, 1992; Pirazzoli et al. 1993; Bard et al., 1996). Terrace 0 corresponds not only to the presently forming coral reef platform, but also to remnants of emerged Holocene reefs that form a small (20-30 m wide) conglomerate platform elevated approximately $1.5 \mathrm{~m}$ above MSL (Pirazzoli et al. 1993). Based on eight U/Th dates, Jouannic et al. (1988) proposed a preliminary range of uplift rates from 0.1 to $0.9 \mathrm{~mm} . \mathrm{yr}^{-1}$. Nineteen new U/Th dates within the terrace sequence led Pirazzoli et al. (1991, 1993) to propose that uplift was relatively constant for the last $600 \mathrm{ka}$, ranging from 0.40 to 0.55 mm. $\mathrm{yr}^{-1}$. On Sumba Island, this relatively low uplift rate led to the reoccupation of some preexisting terraces by more recent coral reefs (Pirazzoli et al. 1991, 1993), resulting in the formation of compound or polycyclic terraces. For this reason, Pirazzoli et al. (1991, 1993) described TI and TII as created during MIS 5, 7 and 9. There is only one terrace level that Pirazzoli et al. $(1991,1993)$ attributed to a single highstand: terrace IIIb, correlated to MIS 11. This terrace, which is found at an elevation of $190 \pm 10 \mathrm{~m}$ on Cape Laundi (Pirazzoli et al. 1993), constitutes our morphological benchmark in this study.

\section{Materials and methods}

In this section we describe how we used the coastal sequences of coral reef terraces to quantify the uplift rates and document how their variations affect landscape morphology.

\subsection{Quantification of coastal vertical displacement}

Paleoshorelines are most easily recognizable where they are closely spaced and constitute staircase coastal sequential morphologies (e.g., Chappell et al. 1974b; Pedoja et al., 2011, 
2014). Sequences (also referred as "series" or "flights") of strandlines shape many coastlines, and are interpreted as imprints of past sea-level variations throughout the duration of uplift. Three main types of paleoshorelines are recognized: erosional (e.g. marine terrace and notch), depositional (e.g. beach-ridge), and constructional (e.g. coral reef), the latter of which occurs on Sumba Island. All types of ancient coral reefs (atolls, barriers, and fringing reefs) are found above sea level, but the most common are fringing reefs that form terraces (Chappell et al., 1974b). Corals and other reef-building organisms such as algae live within the photic zone, rarely deeper than $100 \mathrm{~m}$, and are limited upwards by intertidal emersion (Montaggioni and Braithwaite, 2009). A coral reef terrace can be considered as a fossil reef flat or fossil reef platform. Modern reef flats are stony expanses of reef rocks with a flat surface (Pirazzoli, 2005). This surface is limited toward the sea by a reef crest ( 0 to $2 \mathrm{~m}$ deep) and an external slope (from 0 to $100 \mathrm{~m}$ depth), while toward the continent, it is bounded by a break in slope sometimes underlined by a notch (e.g. Darwin, 1842; Montaggioni and Braithwaite, 2009). Of all the above mentioned morphologies, the notch and the reef crest are the best geomorphic indicators for late Cenozoic paleo-sea levels (e.g. Burbank and Anderson, 2012). In our study, we use only the elevation of the reef crest because, unlike notches, this marker is easily recognizable on satellite images.

To define the levels of coral reef terraces, we first focused on Cape Laundi (Figs. 2 and 3), because the local chrono-morpho-stratigraphy is best established there (Pirazzoli et al., 1991, 1993; Hantoro, 1992; Bard et al., 1996). To systematically map the sequence of reef crests, we extracted hillshade, contour, and slope maps from a 90-m resolution Shuttle Radar Topography Mission (SRTM) digital elevation model (DEM) using ESRI's ArcGIS10 software. We combined these maps with satellite images from Google Earth (August 2012) to 
identify and manually extract the terrace positions. The vertical precision of the SRTM DEM is $10 \mathrm{~m}$ (Farr et al., 2007).

We numbered the coral reef crests following the convention of previous authors (from I to VI, e.g., Pirazzoli et al. 1991). We validated our method by comparing our map of coral reef terraces on Cape Laundi to the map published by Pirazzoli et al. (1991) (Fig. 3). After this initial validation, we mapped the reef crests over the whole coastal stretch covered by sequences of reefal terraces. Two reef crests are continuous laterally and evident on the DEM: terrace II (MIS 5, 7 and 9) and terrace IIIb (MIS 11). Terrace II is polycyclic as discussed above, and impossible to correlate with a single highstand. Hence, we choose terrace IIIb, correlated to MIS $11(400 \pm 20 \mathrm{ka})$, as a morphological and tectonical benchmark. This terrace is found at an elevation of $190 \pm 10 \mathrm{~m}$ on Cape Laundi (Pirazzoli et al. 1993). Consequently, we extended the chronostratigraphy established at the Cape Laundi site to the whole northern coast of Sumba Island. The elevation of the selected benchmark (terrace IIIb, MIS 11) extracted from the DEM yields an apparent coastal uplift rate $(V)$ :

$$
V=\frac{E}{A_{\mathrm{RC}}}
$$

where $E$ is the elevation of the reef crest and $A_{\mathrm{RC}}$ is the age of this reef crest. Because the whole zone is micro to meso tidal (spring tide range $\sim 2.2 \mathrm{~m}$ ), the influence of tides falls within the margin of error $(0>$ reef crest $>-2 \mathrm{~m})$. The eustatic corrections associated with the MIS 11 highstands ( $-1 \pm 1 \mathrm{~m}$ in Bintanja et al., 2005, and $-2 \pm 1 \mathrm{~m}$ in Siddall et al., 2006) also fall within the margin error, implying that calculated apparent uplift rates approximate the net uplift rates.

We next divided the area covered by reefal terraces according to specific ranges of uplift rates. We defined twelve ranges of uplift rates with an increment of $0.05 \mathrm{~mm} \cdot \mathrm{yr}^{-1}$ between 0.1 
and $0.6 \mathrm{~mm} \cdot \mathrm{yr}^{-1}$. This approach divides the area into 30 sections of various spatial extent (Fig. 4a) that generally integrate several catchments. These zones of coastal uplift rates cover from 83 to $438 \mathrm{~km}^{2}$ of coral reef terraces (Fig. 4a, Table 1) and represent 16 to $53 \mathrm{~km}$ of shoreline length (Fig. 4b). These zones serve as calibration (or standardization) sites of the tectonic signal while excluding the undesired effects of heterogeneous lithology. We chose to calculate the average of the morphometric indices values for zones of the same range of uplift weighted by their area to put greater emphasis on the areas that are large enough to obtain representative morphometric average values (Table 1).

\subsection{Morphometric analysis of drainage and catchments of Sumba Island}

We investigated the relationships between morphometric indices and coastal uplift rates obtained through the elevation of dated reefal terraces. Our morphometric analysis of Sumba Island focused on three spatial scales. First, we calculated the following four morphometric indices at the island scale: residual relief, incision, the stream length index $(S L)$, and the normalized steepness index $\left(k_{\mathrm{sn}}\right)$. Second, we investigated the coastal fringe covered by coral reef terraces. For this part, we extracted the four morphometric indices along 30 sectors of coral reef terraces, binned according to 12 ranges of uplift rates (see Section 3.1 and Table 1). Finally, we focused on 15 catchments distributed along the northern and eastern coasts of the island that encompass Quaternary reefal limestones (at least 30\% of the catchment; Fig. 2). For these catchments, we extracted eight morphometric indices including four additional ones relevant to the catchment scale: the hypsometric integral, mean relief, area, and the shape factor. To look for correlations between the eight morphometric indices and uplift rates, we plotted each index as a function of uplift rate.

Catchment boundaries and channel networks were automatically derived from the SRTM DEM. To investigate the effect of lithology on landscape morphology, we use the synthetic 
geological map shown in Fig. 2. Although spatial variations in climate can also influence lateral variations in landscape morphology (e.g., Tucker and Bras, 1998; Roe et al., 2003; Whipple, 2009), we postulate that this parameter is uniform over the studied zone, being classified as an equatorial winter dry climate according to the Köppen-Geiger climate classification (Kottek et al., 2006), with mean annual precipitation of $459 \mathrm{~mm}$ and a mean annual temperature of $26.4^{\circ} \mathrm{C}$ (data from the observing station of Waingapu airport in Sumba Island).

\subsubsection{Hypsometric integral (HI index)}

The hypsometric integral $(H I)$ is a non-dimensional metric representing the proportion of the catchment above a given elevation (Strahler, 1952):

$$
H I=\int_{\text {Min el. }}^{\text {Max el. }} a \mathrm{~d} h
$$

The hypsometric integral is the sum of all the value of all the area $(a)$ between the divide and a contour line of elevation $h$ comprised between the maximum elevation (Max el.) and the minimum elevation (Max el.) of a catchment. Thus, the $H I$ can be viewed as the standardized fractional volume of a basin that has not yet been eroded. Catchment hypsometry is frequently used as an indicator of landscape evolution and as a tool to detect tectonically active areas (Mayer, 1990; Lifton and Chase, 1992; Willgoose and Hancock, 1998; Keller and Pinter, 2000; Brocklehurst and Whipple, 2004). Concave hypsometric curves and low HI values ( $\leq$ 0.3) are associated with stable, mature relief, while convex curves and high $H I$ values $(\geq 0.6)$ indicate unstable, young relief (Strahler, 1957). However, HI is sensitive to rock strength (lithology) and drainage area (Strahler order) when steady state topography has not been reached (Cheng et al., 2012). To avoid these complications, we calculated this parameter for catchments with roughly homogeneous lithology and similar drainage areas. 


\subsubsection{Shape factor}

The Shape factor $(S h p)$ is an indicator of the elongation of a catchment. This index is defined by the equation:

$$
\operatorname{Sh} p=\frac{\sqrt{A}}{d}
$$

where $d$ is the catchment diameter (i.e., maximum distance between any two points of the catchment boundary) and $A$ is the catchment area.

\subsubsection{Relief}

Relief can be defined in a number of ways (e.g. Champagnac et al. 2014). Here, we calculated three parameters that attempt to capture the whole catchment relief: mean relief, residual relief, and incision. The mean catchment relief is defined as the difference between the mean elevation of a catchment and the elevation of its outlet (Delunel et al., 2010). This value is dependent on the drainage area. The residual relief (also named "local relief"; Ahnert, 1984) is the difference between the envelope surface (i.e. the surface constructed from ridge-lines) and the subenvelope surface (i.e., the surface constructed from channel-bottom points; e.g. Hilley and Arrowsmith, 2008, Yildirim et al. 2011). The envelope map is an imaginary topographic surface tangent to ridge crests (Bullard and Lettis, 1993), while the subenvelope map provides a hypothetical topographic map of the land surface eroded to the level of the streams (Stearns, 1967). Incision (or "geophysical relief"; Ahnert, 1984) is defined as the difference between the envelope surface and the current topography (e.g. Burbank and Anderson, 2012). It yields minimum values because undissected surface remnants are not present everywhere and interfluves are arbitrarily considered to be uneroded.

\subsubsection{Stream gradient indices (SL and $\left.k_{\mathrm{sn}}\right)$}


The typical shape of longitudinal river profiles is semi-logarithmic, concave-up, and smooth under steady tectonic and climatic conditions (e.g. Hack, 1957; Whipple 2001; Tucker and Whipple, 2002). Deviations from this equilibrium form are interpreted as a consequence of variations in lithology, climate, sediment flux, base level, or rock uplift (Wobus et al., 2006a; Kirby and Whipple, 2012). To illustrate such gradient variations on streams of Sumba Island, we extracted longitudinal profiles of the longest channel of the 15 catchments studied, and also two channel slope indices: the stream-gradient index $(S L)$ and the steepness index $\left(k_{\mathrm{s}}\right)$.

$S L$ was defined by Hack (1973) and is an expression for channel slope as a function of distance downstream:

$$
S L=\frac{\mathrm{d} H}{\mathrm{~d} L} L
$$

where $L$ is the distance upstream measured along the thalweg of the stream, and $\mathrm{d} H / \mathrm{d} L$ is the local channel gradient. Under steady state conditions and uniform lithology, climate, and sediment flux, the value of $S L$ is constant all along the profile (Hack, 1973). $S L$ has been used to detect tectonic activity based on the morphology of coastal streams (Merritts and Vincent, 1989). However, interpretations of the index require caution, because the value depends on the choice of the equilibrium profile shape and on the relationship between discharge and drainage area. We calculated this parameter for each 1-km-long river segment of the entire island.

We also calculated $k_{\mathrm{s}}$ for each river segment, a morphometric parameter currently more commonly used than $S L$ (e.g., Wobus et al., 2006b; Yildirim et al., 2011; Kirby and Whipple, 2012; Miller et al., 2013; Haghipour and Burg, 2014; Castillo et al., 2014). Under steady state conditions, fluvial channels tend to follow a power-law relationship (Flint, 1974):

$$
S=k_{\mathrm{s}} a_{u}^{-\theta}
$$


where $S$ is the channel slope, $a_{\mathrm{u}}$ is the upstream catchment area, and $\theta$ is the concavity index (Wobus et al., 2006b). Because concavity varies among rivers and that variation leads to large changes in $k_{\mathrm{s}}$, the steepness index is often expressed in a normalized form, $k_{\mathrm{sn}}$, by using the

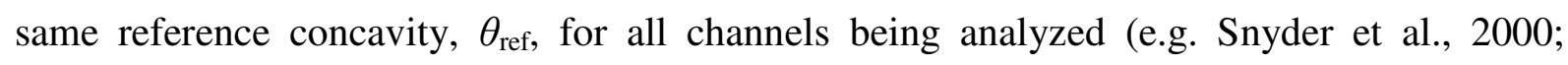
Duvall et al., 2004; Kirby and Whipple, 2012):

$$
S=k_{\mathrm{sn}} a^{-\left(\theta_{\mathrm{ref}}\right)}
$$

where $\theta_{\text {ref }}=0.45$ is most commonly used in the literature. $k_{\mathrm{sn}}$ allows for effective comparison of stream profiles with greatly varying drainage area (Kirby and Whipple, 2012).

We analyzed all channels with a drainage area larger than $1 \mathrm{~km}^{2}$ and calculated the $k_{\mathrm{sn}}$ value over each $1-\mathrm{km}$-long segment of the rivers. We then averaged all $k_{\mathrm{sn}}$ values of the river segments for each catchment following Ouimet et al. (2009).

\section{Results}

\subsection{Coastal tectonic uplift}

The results of our remote mapping procedure of coastal terrace sequences (Fig. 2) are in good agreement with previous field based maps on Cape Laundi (Hantoro, 1992; Pirazzoli et al., 1991, 1993; Bard et al., 1996). We roughly estimated that uncertainties for the elevation of each the reef crest is $\pm 50 \mathrm{~m}$ (horizontal) and $\pm 10 \mathrm{~m}$ (vertical). These uncertainties are important for low standing features and in some cases can result in erroneous results and interpretations. For example, a coral reef terrace associated with MIS 11 (our morphologic and tectonical benchmark) at $9 \mathrm{~m}$ in elevation theoretically implies that the coast could be uplifted, stable, or subsided. The two latter interpretations are invalidated by the occurrence of 
emerged coastal sequences (Fig. 2). As a consequence, for the low-standing terraces $(<9 \mathrm{~m})$, we assumed a special margin of error of $\pm 10 \%$ of the measured elevation.

Sequences of coral reef terraces cover $350 \mathrm{~km}$ along the coast of Sumba Island and are better developed on capes (Karoso, Sasar, Laundi and Undu capes; Fig. 2). The sequences of coral reef terraces are up to $30 \mathrm{~km}$ wide and reach a maximum elevation of $470 \mathrm{~m}$ on Cape Laundi. There, the six main terraces (I to VI) were used as a reference to test the accuracy of our analysis because they exhibit the best morphologic preservation. On the major capes, the terrace associated with the MIS 11 reef crest forms a larger step in the coastal staircase morphology. The elevation of the MIS 11 reef crest reveals tilts and offsets reflecting spatially variable uplift rates.

On the N-S elevation profile on Cape Karoso (A-B profile), the MIS 11 shoreline is tilted northward from 240 to $25 \mathrm{~m}$ in elevation (Fig. 5). To the south, the MIS 11 benchmark is offset by the displacement along a gravitational normal fault with a throw of $150 \mathrm{~m}$.

On the $\mathrm{W}-\mathrm{E}$ elevation transect (profile $\mathrm{A}-\mathrm{B}-\mathrm{C}$ on Fig. $5 \mathrm{~b}$ ), which spans the western part of the island from Cape Karoso to Cape Sasar, the MIS 11 shoreline exhibits its lowest elevation and ranges from 20 to $100 \mathrm{~m}$ along a 110-km-long coastal stretch (Fig. 5). The MIS 11 reef crest benchmark is sub-horizontal (elevation ranging from 20 to $50 \mathrm{~m}$ ) over the first $55 \mathrm{~km}$ of the profile and rises from 30 to $100 \mathrm{~m}$ (on Cape Sasar) over the second half of the profile. On the NW-SE topographic profile, from Cape Sasar to Cape Undu (profile B-C on Fig. 5b), the MIS 11 reef benchmark is higher than elsewhere on the island overall and shows a major upward flexure with a maximum elevation of $\sim 250$ m located near the Kambaniru River (Fig. $5)$. 
We converted the present-day elevations of the MIS 11 benchmark into mean coastal uplift rates that average over the last $\sim 400 \mathrm{ka}$. These rates are highest east of Cape Laundi $(0.63 \pm$ $\left.0.05 \mathrm{~mm} . \mathrm{yr}^{-1}\right)$ and lowest on Cape Karoso $\left(<0.07\right.$ mm.yr $\left.{ }^{-1}\right)$ (Fig. 5a). Along the northern Sumba Island coast, we calculated an uplift rate lower than $0.3 \mathrm{~mm} \cdot \mathrm{yr}^{-1}$ for the western zone, and 0.3 to $0.6 \mathrm{~mm} \cdot \mathrm{yr}^{-1}$ for the eastern zone.

\subsection{Morphometric analysis}

All the calculated morphometric characteristics of the catchments are listed in Table 2. In describing the results, we first focus on the morphology of the whole island, then the coral reef zones and finally the individual catchments draining the sequences of coral reef terraces.

\subsubsection{Morphometric analyses of the whole island}

Incision and residual relief were determined using the envelope and the subenvelope surfaces produced with the highest and lowest points of the topography, respectively (Fig. 6). The values of residual relief range from 0 to $526 \mathrm{~m}$ and values of incision range from 0 to $478 \mathrm{~m}$ (Fig. 6a). The southern coastal fringe of Sumba Island exhibits high residual relief values, in particular for the Kambaniru Catchment, on the southern slopes of the Kannanggar Massif (KM, Fig. 6). Low residual relief values are characteristic of the sequences of coral reef terraces and the top of the Waikabubak Plateau.

Similarly, incision is low on the coral reef terrace area $(<20 \mathrm{~m})$ and on the tops of the Waikabubak Plateau and the Kannanggar Massif $(<100 \mathrm{~m})$ (Fig. 6b). Across the island, at a large scale, residual relief and incision values are lower in the west than in the east. 
A comparison among topography, residual relief and incision parameters allows us to identify four distinct geomorphic areas: 1) the highest topography and the greatest erosion occur around the Kannanggar Massif (KM); 2) high elevations and relatively low erosion occur on the top of the Waikabubak Plateau and the Kannanggar Massif; 3) low topography and rapid erosion are recorded on the southern coast of Sumba Island, including Sendikari Bay and Kekadu Bay; and 4) low topography and slow incision dominate on the coastal stretch covered by the coral reef terraces.

Values of the $S L$ range from 2 to $3000 \mathrm{~m}$ with a mean of $186 \mathrm{~m}$, while $k_{\mathrm{sn}}$ ranges from 0.5 to $422 \mathrm{~m}^{0.9}$ with a mean of $37 \mathrm{~m}^{0.9}$ (Fig. 6). Across the study area, the patterns in the $k_{s n}$ and $S L$ values are similar. The flanks of the Kannanggar Massif and the Waikabubak Plateau are characterized by high values of $S L(>300 \mathrm{~m})$ and $k_{\mathrm{sn}}\left(>60 \mathrm{~m}^{0.9}\right)$ (Fig. 6). High values of $S L$ (> $600 \mathrm{~m})$ and $k_{\mathrm{sn}}\left(>90 \mathrm{~m}^{0.9}\right)$ are sometimes localized on the paleo-sea-cliff of the coral reef terraces, as observed on capes Undu, Laundi, Sasar, and Karoso (Fig. 6d). These high values are surrounded by values lower than $250 \mathrm{~m}$. Low values of $S L(<250 \mathrm{~m})$ and $k_{\mathrm{sn}}\left(<10 \mathrm{~m}^{0.9}\right)$ also occur on the coral reef terraces, especially on capes Karoso and Undu except locally on paleo-sea-cliffs, and on top of the Waikabubak Plateau and the Kannanggar Massif (Fig. 6).

\subsubsection{Morphometric analyses of coral reef zones with similar uplift rates}

On the coral reef sequence, the values of residual relief averaged across zones of similar uplift rates range from 18 to $67 \mathrm{~m}$ (Fig. 7a). The zone of similar uplift used to extract morphometric indices are represented in Fig. 7i. Values of incision averaged across the same zones are between 15 and $35 \mathrm{~m}$ (Fig. 7c). For residual relief and incision, the correlation with uplift rates is poor to null, with $R^{2}$ values for linear fitting of 0.31 and 0.007 , respectively (Fig. $7 b, d)$. 
Values of $S L$ averaged in each uplift rate zone range from 84 to $231 \mathrm{~m}$ (Fig. 7e), and values of $k_{\mathrm{sn}}$ range from 16 to $36 \mathrm{~m}^{0.9}$ (Table 1 , Fig. $7 \mathrm{~g}$ ). For the $S L$ and $k_{\mathrm{sn}}$ indices, the correlation coefficients with uplift rates of the linear fit are 0.60 and 0.56 respectively (Fig. $7 f, h)$. We note that highest values for all four indices correspond to highest uplift rates.

\subsubsection{Morphometric analyses of individual catchments}

We analyzed 15 catchments that encompass coral reef terraces, between $30 \%$ and $100 \%$ of the drainage area, with eight of the catchments consisting of $70 \%$ coral reef terraces (Table 2, Fig. 7). All the catchments drain the total sequence of coral reef terraces. The mean slope of the shelf ranges from 0.015 (catchment 15) to 0.2 (catchment 4). To reduce spatial scale biases, we selected catchments with outlet Strahler orders ranging from 3 to 5 . We plotted each morphometric index as a function of mean coastal uplift rate deduced from the sequences of dated, emergent coral reef terraces (Table 2, Fig. 9).

The drainage areas of the 15 selected catchments range from 16 to $113 \mathrm{~km}^{2}$ with a mean of $\sim 60 \mathrm{~km}^{2}$ (Fig. 8a). The smallest catchments are near Cape Laundi, whereas the largest catchments are on capes Karoso and Undu. The coefficient of correlation of the linear fit between drainage area and uplift rate is low $\left(R^{2}=0.30\right.$, Fig. 9a). Nonetheless, the smallest catchments $\left(<45 \mathrm{~km}^{2}\right)$ are systematically affected by high uplift rates $\left(>0.3 \mathrm{~mm} . \mathrm{yr}^{-1}\right)$, while larger catchments correspond to a wider range of uplift rates with an overall smaller magnitude.

The values of mean relief for the 15 catchments vary from 103 to $411 \mathrm{~m}$ with an average of $241 \mathrm{~m}$ (Table 2, Fig. 8b). Catchments with high relief (> $350 \mathrm{~m}$ ) dominate in Cape Laundi (catchments 7, 8 and 9), whereas catchments with low relief $(<150 \mathrm{~m})$ are at Cape Karoso 
(catchments 1 and 3). The $R^{2}$ value for the linear correlation of mean relief and uplift rate is relatively low at 0.41 because the dispersion is large for the low values of relief. Nonetheless, high values of mean relief (>250 m) only occur in rapidly uplifting catchments $\left(>0.4 \mathrm{~mm} \cdot \mathrm{yr}^{-}\right.$ 1; Fig. 9b), while the catchments with low mean relief (between 100 and $250 \mathrm{~m}$ ) have been uplifting at a wide range of rates. This pattern suggests that high mean relief values indicate rapidly uplifting areas, while low relief areas may be largely non-diagnostic of uplift rates.

The distribution of $H I$ values is similar to that of the mean relief values. Values of $H I$ range from 0.25 to 0.70 , with a mean of 0.45 (Table 2, Fig. 8c). Catchments with the lowest $H I$ values are located on capes Karoso and Undu (catchment 1, 2, 3, 4, 14 and 15). The four catchments on Cape Laundi (catchments 6, 7, 8 and 9) record the highest $H I$ values. Only the catchments undergoing high coastal uplift rates $\left(>0.3 \mathrm{~mm} . \mathrm{yr}^{-1}\right)$ have high $H I$ values $(>0.55$; Fig. 9c), although the linear correlation with uplift rate is low $\left(R^{2}=0.5\right)$. Here again, our data indicate that only high values of $H I$ correspond to fast uplifting areas, while low values of $H I$ can occur under any uplift rate.

The shape factor ranges from 0.26 to 0.66 with a mean of 0.44 . Most elongated catchments, with the factor values between 0.2 and 0.4 (catchments $6,7,8,10,11,12,13$ and 14), are located between capes Laundi and Undu (Fig. 8d). The most rounded catchments are founded in Cape Karoso, with shape factor values of 0.6 to 0.7 (catchments 1 through 4). For catchments undergoing high coastal uplift rates $\left(>0.3 \mathrm{~mm} . \mathrm{yr}^{-1}\right)$, the shape factor is lower than 0.5. A linear regression between the shape factor and the uplift rate yields an $R^{2}$ value of 0.77 (Fig. 9d), although the good correlation may be dominated by the few catchments (1-4) from Cape Karoso that are consistently circular and have very low uplift rates compared to others. 
The bimodal distribution of Fig. 9d nevertheless suggests that only fast uplifting catchments are elongated and that those that are uplifting at low rates are systematically rounded.

Values of residual relief extracted by catchment range from $20 \mathrm{~m}$ (catchment 10, Cape Laundi) to $106 \mathrm{~m}$ (catchment 8, Cape Laundi) (Fig. 8e). Values of incision extracted by catchment range from $5 \mathrm{~m}$ (catchment 10, Cape Laundi) to $48 \mathrm{~m}$ (catchment 3, Cape Karoso) (Table 2, Fig. 8f). For these two parameters, correlations with uplift rates are negligible $\left(R^{2}<\right.$ 0.01; Fig. 9 e,f). Furthermore these indices do not seem to be characterized by a bimodal distribution.

Values of $S L$ extracted by catchment range from $41 \mathrm{~m}$ on Cape Karoso (catchment 1) to 276 m on Cape Laundi (catchment 9), with a mean of $144 \mathrm{~m}$ (Fig. 8g). Values of $k_{\mathrm{sn}}$ averaged over individual catchments range from $13 \mathrm{~m}^{0.9}$ on Cape Karoso (catchment 1 ) to $52 \mathrm{~m}^{0.9}$ on Cape Laundi (catchment 8), with a mean of $30 \mathrm{~m}^{0.9}$ (Fig. 8h). The steepest catchments are located on Cape Laundi (Table 2, Fig. 8g,h). The coefficient of linear correlation with uplift rate is low for both $S L\left(R^{2}<0.52\right.$, Fig. $\left.9 \mathrm{~g}\right)$ and $k_{\mathrm{sn}}\left(R^{2}=0.19\right.$, Fig. 9h). Again, high $S L$ and $k_{\mathrm{sn}}$ values occur only in fast uplifting (>0.3 mm.yr $\left.{ }^{-1}\right)$ catchments. In turn, steep catchments $(>160 \mathrm{~m}$ for $S L$ and $>33 \mathrm{~m}^{0.9}$ for $k_{\mathrm{sn}}$ ) indicate fast uplifting areas (Fig. $9 \mathrm{~g}, \mathrm{~h}$ ).

\subsubsection{River longitudinal profiles}

One factor that can significantly influence the relationship between uplift rates and morphometric indices is whether or not the landscape is in steady-state where erosion everywhere is equal to uplift. Under conditions of uniform lithology, climate, and uplift rates, river channels tend to be concave and smooth at steady-state and linear to convex with knickpoints when not (e.g., Whipple and Tucker, 1999). As such, river longitudinal profiles 
can provide a means to test if the river channel (or some portion of it) has fully adjusted to external forcing. While many knickpoints may be associated with transient responses to changes in uplift rates or lithologic boundaries, in coastal zones, knickpoints can alternatively be produced by base level variations (Snyder et al., 2002).

Across Sumba Island, all stream profiles show knickpoints that sometimes strongly influence the profile shape (Fig. 10). Across the study area, streams 1-4, 14, and 15 show concave profiles, streams 5 and 10-13 have almost linear profiles, and streams 6-9 have much concave long profiles (Fig. 10). At this scale, streams undergoing the highest uplift rates are farther from steady-state than those undergoing the lowest uplift rates. In more detail, the long profiles of the streams show knickzones that are sometimes linked to the trough of a paleosea-cliff (e.g. streams 8 and 15; Fig. 10). Major knickzones are also typically associated with the contact between the Waikabubak or Kannanggar unit and the reefal limestone (e.g. streams 2, 3, 4, 9 and 14).

\section{Discussion}

\subsection{Relationship between uplift rates and morphometric indices}

\subsubsection{Incision and relief}

Our results show no evident linear correlation of uplift rates with incision $\left(R^{2}=0.007\right.$ for uplift rate zones and 0.01 for individual catchments), residual relief $\left(R^{2}=0.31\right.$ for uplift rate zones and 0.0003 for individual catchments), or mean relief $\left(R^{2}=0.41\right)$ (Figs. 7 and 9). These different measures of topographic relief reflect generally the erosion rate (e.g., Montgomery and Brandon, 2002; Von Blanckenburg, 2005; Champagnac et al., 2014). In steady state topography, fluvial and hillslope erosion rates balance rock uplift rates. Relief should thus be correlated also with the uplift rate. The poor first-order correlations that we found between 
topographic relief and uplift rate can be explained by the largely transient state of the drainages along the coast of Sumba Island, as indicated by the occurrence of numerous knickpoints along the stream long profiles, especially where streams cross a paleo-sea-cliff (Fig. 10). The common occurrence of transience along the coastal drainages could be due to the youthfulness of the emerged terrain $(<1 \mathrm{Ma})$ and associated karst development, the high strength of the reefal limestone, and/or the small size and low discharge of most of the catchments, all of which can slow landscape responses to external forcing (Snyder et al., 2002, Wobus et al., 2006b, Crosby et al., 2007; Schildgen et al., 2012). Furthermore, because the coral reef shelf is preserved and perched during uplift, the offshore wave-base erosion can be considered negligible. Consequently, because Quaternary sea level fluctuations without offshore wave-base erosion during uplift induce channel lengthening and an overall increase of relief, a true steady state in this type of setting may be impossible to attain (Snyder et al., 2002).

Despite the overall poor correlation between uplift and relief, the correlation of residual relief and incision extracted by the uplift rate zone is high where uplift rates are $<0.3 \mathrm{~mm} \cdot \mathrm{yr}^{-1}\left(R^{2}=\right.$ 0.79 and 0.69 , respectively) (Fig. 7b). Low uplift rates led to high correlations between uplift rate and relief, and consequently steady state conditions (e.g. Snyder et al., 2000). Hence, we can interpret the $0.3 \mathrm{~mm} \cdot \mathrm{yr}^{-1}$ uplift rate as a threshold below which the streams are generally able to incise at a rate equal to the imposed uplift rate; at higher uplift rates, the channels may be more likely to become hanging, resulting in transient morphologies that can persist for long periods within the landscape (e.g., Wobus et al., 2006b; Crosby et al., 2007).

However, this interpretation does not work at the catchment scale. Residual relief and incision values of catchments $1,2,3$ and 4 , which are affected by low uplift rates $\left(<0.3 \mathrm{~mm} \cdot \mathrm{yr}^{-1}\right)$, are 
not correlated with uplift rates (Fig. 9e,f). This discrepancy could be explained by the impact of the lithological change (Waikabubak unit/Quaternary reefal limestones) within the catchments. (Fig. 10), which could induce variations in relief not associated with tectonic forcing.

\subsubsection{SL and $k_{s n}$}

Positive linear correlations have been observed between $k_{\mathrm{sn}}$ and erosion rate (equivalent to uplift rate for steady-state topography) when erosion rates are moderate (e.g. Miller et al., 2013), but typically become non-linear at higher erosion rates (e.g. Binnie et al., 2007; Ouimet et al. 2009; DiBiase et al. 2010; Scherler et al. 2014). In our study, $S L$ and $k_{\text {sn }}$ extracted by uplift rate zone show moderate positive correlations with uplift rates $\left(R^{2}=0.6\right.$ for $S L$ and $R^{2}=0.56$ for $k_{\text {sn }}$; Fig. 7f, h). Correlation coefficient values drop to 0.52 for $S L$ and 0.19 for $k_{\mathrm{sn}}$ at the catchment scale (Fig. $\left.9 \mathrm{~g}, \mathrm{~h}\right)$.

Apart from the changing lithology within several catchments, which may at least partly explain the weaker correlations at the catchment scale, the transient nature of many channels make $k_{\mathrm{sn}}$ and $S L$ indices more challenging to interpret (Wobus et al., 2006a,c). Furthermore, on the sequences of reefal terraces, zones of high gradient along channels are due to the original staircase morphology of the coral reefs (Fig. 10). Indeed, values of $k_{\mathrm{sn}}$ and $S L$ increase when channels cross a paleo-sea-cliff (eroded fossil fore-reef in some cases) because this step is not yet totally incised by channel. Only on average, higher uplift rates create higher paleo-sea-cliffs and steeper channels (Fig. 10). Following models developed by Snyder et al. (2002), knickpoints produced by glacio-eustatic sea level fluctuations are favored by a steep offshore ramp. Thus, the morphology of the shelf could influence the morphometric parameters sensitive to the knickpoints along channel profiles, such as the $S L$ or the $k_{\mathrm{sn}}$ indices. To test this influence on our results, we compare coastal catchments affected by 
similar uplift rates but with different shelf slope gradients. Only catchments 13, 14 and 15 undergo the same range of uplift rates but differ strongly in their offshore slope gradients (from 0.015 to 0.07 ). Yet, values of $S L$ and $k_{\mathrm{sn}}$ for these three catchments are very similar (Table 2). Consequently, the shelf morphology seems to have a relatively minor influence on the basin morphology and our calculated morphometric indices (Fig. 10).

\subsubsection{HI and shape factor}

$H I$ values are calculated with the drainage area and elevations along the profile, and in our study, they have a weak positive correlation with uplift rates $\left(R^{2}=0.5\right)$. Interestingly, hypsometric curves for coastal watersheds on marine terraces in Greece have shapes largely influenced by the staircase morphology (see Fig. 10 in Maroukian et al., 2008). Even if the origin of terraces differs from our study (marine terraces $v s$ coral reef terraces), the staircase morphology is common. Hence, the particular morphology of the coral reef terraces appears to also influence $H I$, and may partly explain the relatively low correlation coefficient for Sumba Island.

Shape factor values increase with uplift rate, and shows the highest correlation of all indices included in our study $\left(R^{2}=0.77\right)$. The hypothesis that catchment length increases with uplift (Bull and Mcfadden, 1977; Kale and Shejwalkar, 2008) seems valid within the coral reef zone. Lengthening could be favored when uplift rate increases, because more land is rapidly exposed (Snyder et al., 2002). This interpretation is further reinforced by the fact that only slowly uplifting areas yield rounded catchments.

\subsubsection{Thresholds and bimodal distributions of the morphometric indexes/uplift rates plot}


At the catchment scale, four morphometric indices ( $H I$, shape factor, $S L$ and mean relief) are moderately to highly correlated with uplift rates, but the linear correlations are not strong enough to determine quantitatively uplift rates from values of morphometric indices. However, the distribution of geomorphic parameters values in relation to uplift rate reveals a bimodal distribution about a threshold for the uplift rate $\left(\sim 0.3 \mathrm{~mm} \cdot \mathrm{yr}^{-1}\right)$, above which many indices yield high values (Figs. 7 and 9). All the catchments with an area larger than $45 \mathrm{~km}^{2}$, a mean relief higher than $250 \mathrm{~m}, H I$ higher than 0.55 , a shape factor lower than $0.45, S L$ higher than $160 \mathrm{~m}$ or $k_{\mathrm{sn}}$ higher than $33 \mathrm{~m}^{0.9}$ have uplift rates higher than $0.3 \mathrm{~mm} . \mathrm{yr}^{-1}$. Below 0.3 mm.yr ${ }^{-1}$, morphometric indices fail to distinguish slowly uplifting areas from rapidly uplifting areas with the exception of the shape factor. At the scale of uplift rate zones, we observed the same pattern for $k_{\mathrm{sn}}$ and $S L$ values (Fig. 7f,h). The threshold of uplift rate in Sumba is $\sim 0.3$ mm. $\mathrm{yr}^{-1}$, but if such thresholds exist in other landscapes, the value may change according to the external forcing (viz. climate) and the size of studied catchments.

\subsection{Effects of spatial scales of morphometric indices extraction on their correlation with} uplift rates

With our different scales of observation (whole island, coastal reef zone, and catchment), we can assess which scale is most appropriate for calculating morphometric parameters that are most representative of uplift-rate variations. The morphometric indices $\left(S L, k_{\mathrm{sn}}\right.$, incision and residual relief) are better correlated with uplift rates when they are averaged according to uplift rate zones rather than by individual catchments. Several reasons could explain this result. First, each uplift rate zone is larger than each catchment (Fig. 5 and 8), providing a more representative average morphometric value. Second, with the catchment-based approach, it is difficult to isolate regions that drain only coral reef sequences. The change of lithology within many catchments may imply variations of landscape erodibility, affecting 
both hillslope and channel morphometric indices (e.g., Duvall et al., 2004). However, even if several large knickpoints are located at lithologic contacts (Fig. 10), many of the variations in catchment morphometric indices cannot be explained by lithologic differences. For example, catchments 10 and 12 experience similar uplift rates and both drain mostly reefal limestones (Fig. 10), but they are only similar in terms of the shape factor and $H I$; for all other indices, catchment 12 shows significantly higher values (Fig. 9). Another complication that may explain the poor results from the catchment scale analysis is that channels upstream from the coral reef zone are likely to have recorded the tectonic and climatic signals prior to the emergence of the coral reef terraces. Our uplift history does not extend beyond that recorded by the emerged Pleistocene terraces, but the morphologic parameters calculated on channels and catchments that extend beyond the coral reef zone could be affected by any temporal changes in uplift rate or climatic conditions.

At the island scale, and at a first approximation, $k_{\mathrm{sn}}$, residual relief and incision values are higher on the Kananggar Massif than on the Waikabubak Plateau (Figs. 4 and 6). According to uplift rates deduced along the northern coast of the island, the Kannanggar Massif is located south of the highest uplift rates, whereas the Waikabubak Plateau is located south of the area of the lowest uplift rates (Fig. 5). Thus, $k_{\mathrm{sn}}, S L$, residual relief, and incision are well correlated with the large wavelength tectonic signal at the island scale, even if the short wavelength tectonic signal detected with the analysis of the sequences of reefal terraces does not appear (e.g. maximum uplift rates in Waingapu Bay, Fig. 5). Interestingly, this pattern exists despite island-scale variations in lithology, which we expect to produce the opposite pattern if the topography is assumed to be at the steady state. In the eastern part of Sumba Island, the Kannanggar Formation, which comprises carbonates and turbiditic sandstones, is most likely weaker than the carbonate rocks of the Waikabubak Formation in the west. From 
lithology alone, we thus expect higher values of relief and slope indices in the west compared to the east if Sumba Island's topography were at the steady state. To explain the obtained results, it is possible that the Waikabubak Formation is actually weaker than the Kannanggar Formation, or lithology plays a minor role compared to uplift-rate variations for the island scale morphology, with some portion of Sumba Island in a transient state. The latter possibility is supported by the distribution of the $k_{\mathrm{sn}}$ and $S L$ values at the island scale. Relatively low erosion highlighted by residual relief occurs on the top of the Waikabubak Plateau and the Kannanggar Massif, and high anomalies of $k_{\mathrm{sn}}$ and $S L$ represent knickpoints all around these zones. These observations argue for a perched low-relief landscape, implying a transient landscape at the island scale. Consequently, the whole island topography does not reflect the Pleistocene uplift recorded by the coral reef terraces.

Overall, our morphometric index values derived from the uplift rate zones with uniform lithology for each, compared to those extracted for individual catchments and across the entire island both of which contain variable lithology, illustrate that the spatial scale of the averaging, the transience of the landscape, and variable lithology can all be significant factors that influence the correlation between various morphometric indices and uplift rates.

\section{Conclusions}

We studied eight morphometric indices and compared them with uplift rates determined from a well-dated sequence of coral reef terraces on Sumba Island, Indonesia. We calculated these indices at three scales: across the whole island, only on areas underlain by sequences of coral reef terraces grouped according to uplift rate zones, and catchments draining mainly the coral reef zones. We analyzed the correlations between these indices and the uplift rates between 0.002 to $0.6 \mathrm{~mm} . \mathrm{yr}^{-1}$. This study allowed us to evaluate which morphometric indices best reflect the spatial variations in the Pleistocene coastal uplift rates. 
Most of the channels are in a transient state due to the recent emergence of the coral reef terraces and the relatively strong lithology of the reefal limestones. When we calculate morphometric indices for uplift rate zones, which are all confined to the reefal limestones, the $S L$ and $k_{\mathrm{sn}}$ indices are well correlated with the uplift rates. However, the staircase morphology together with the transient state of the landscape appear to influence the correlations of uplift rates with residual relief, mean relief, and incision; the correlations improve when we consider only areas undergoing slower uplift $\left(<0.3 \mathrm{~mm} \cdot \mathrm{yr}^{-1}\right)$, where it is more likely that the landscape remains closer to steady state.

At the catchment scale, the shape factor, mean relief, $S L$ and $H I$ indices are well correlated with uplift rates, following a bimodal distribution rather than a linear correlation; in each case, they can be used to detect at a first order qualitative spatial variations in uplift rate. Overall, we found that most indices are effective for identifying rapidly uplifting areas $\left(>\sim 0.3 \mathrm{~mm} . \mathrm{yr}^{-}\right.$ ${ }^{1}$ ) at a catchment scale, although the relationship is not bivalent. While only rapidly uplifting areas can yield high values of mean relief $(>250 \mathrm{~m}), H I(>0.55)$, the shape factor $(<0.5), S L$ (> $160 \mathrm{~m})$ and $k_{\mathrm{sn}}\left(33 \mathrm{~m}^{0.9}\right)$ as well as small drainage areas $\left(<45 \mathrm{~km}^{2}\right)$, rapidly uplifting areas can display morphologies comparable to slowly uplifting areas with the exception of the shape factor index. This result indicates that the set of common geomorphic indices is inappropriate to determine slowly $\left(<\sim 0.3 \mathrm{~mm} . \mathrm{yr}^{-1}\right)$ uplifting areas, but proves to be effective in identifying rapidly uplifting areas.

\section{Acknowledgments}

We thank the ANR GiSeLE for funding, and Ed Keller and an anonymous reviewer for their comments that helped to improve the manuscript. 


\section{Figure and table captions}

Fig. 1. Location and geodynamical setting of Sumba Island. Plate speeds are taken from Hinschberger et al. (2005). The sites of MIS 5e (stars) come from the compilation by Pedoja et al. (2011). Grey shading represents global bathymetry (Smith and Sandwell, 1997).

Fig. 2. Location, geologic map, and distribution of the coral reef terraces of Sumba Island. Synthetic geologic map is from the studies of Effendi and Apandi (1981), Rutherford et al. (2001) and Fleury et al. (2009). The coral reef crests used in this study are mapped in black lines, and the 15 selected catchments are outlined in white. The shelf bathymetry ( 0 to -120 $\mathrm{m}$ ) is shown in grey contour lines (data from the Global Sea Floor Topography of Smith and Sandwell, 1997).

Fig. 3. Sequences of coral reef terraces on Cape Laundi. a) Comparison of systematic mapping from this work (solid contour lines) with mapping from field data and air photos by Hantoro (1992) (dashed contour lines). Each reef crest is represented according to its correlated MIS. b) Cross section of the reference transect of the sequence of coral terraces of Cape Laundi (redrawn from Pirazzoli et al., 1991, 1993). The reef crests are numbered from I to VI following their correlated MIS.

Fig. 4. Topography and uplift rates. a) Area of the 30 sectors of coral reef terraces binned according to their uplift rates. b) Length of the shoreline affected by different uplift rates.

Fig. 5. Sumba Island morphology. a) Coastal mean uplift rates are symbolized by a gradient. The reference reef crest (MIS 11) used to calculate uplift rates is indicated with a dashed black line. Gravitational collapses inferred by Fleury et al. (2009) are in dashed lines and those inferred by our study are in solid lines. b) Two elevation profiles of the MIS 11 coral reef terrace crests.

Fig. 6. Analysis of relief and river channel slopes across Sumba Island. The limit of the coral reef terraces is mapped in solid black line. a) Residual relief. b) Incision illustrated with a gradient. c) Incision (solid line) and residual relief (dashed line) profiles associated with the maps. d) $S L$ of streams. e) $k_{\mathrm{sn}}$ of streams. The two stream indices are symbolized on the streams. WP: Waikabubak Plateau, KC: Kambaniru Catchment, KM: Kannanggar Massif.

Fig. 7. Uplift rates as a function of average value of morphometric indices extracted by zone of similar uplift rates weighted by their area. Panels show values of morphometric indices and associated linear correlation (solid line for all uplift rates and dashed line for uplift rates $<0.3$ mm. $\mathrm{yr}^{-1}$ ): a and b) residual relief; c and d) incision; e and f) $S L$; and $\mathrm{f}$ and g) $k_{\mathrm{sn}}$. The dashed grey line is the threshold of uplift rate of $0.3 \mathrm{~mm} \cdot \mathrm{yr}^{-1}$ and dashed black line is the threshold of the $S L$ and $k_{\mathrm{sn}}$ indices in (f) and (h), respectively. i) show the different uplift range used to extract the morphometric indices. 
Fig. 8. Morphometric indices extracted for the 15 selected catchments. a) Drainage area; b) Mean relief; c) Hypsometric integral; d) Shape factor; e) Residual relief; f) Incision; g) $S L$; h) $k_{\mathrm{sn}}$.

Fig. 9. Linear correlations between the mean value (residual relief, incision, $S L$ and $k_{\mathrm{sn}}$ ) or individual value (area, mean relief, $H I$ and shape factor) of morphometric indices and uplift rates extracted for the 15 catchments. a) Area; b) Mean relief; c) Hypsometric integral; d) Shape factor; e) Residual relief; f) Incision; g) $S L$; h) $k_{s n}$. The dashed grey line is the threshold of uplift rate of $0.3 \mathrm{~mm} . \mathrm{yr}^{-1}$ and dashed black line is the threshold of $H I$, the shape factor, $S L$ and $k_{\mathrm{sn}}$ in (c), (d), (g) and (h).

Fig. 10. Long profiles of streams from the 15 selected catchments and associated uplift rate ranges affecting each catchment. The number for each stream corresponds to the catchment number (Fig. 2a). Reef crests are marked following their associated MIS. The upper vertical thick lines on the top symbolize the river bed lithology. Kr: Kannanggar unit (limestone and turbiditic sandstone); RL: Quaternary reefal limestones; Wk: Waikabubak unit (limestone).

Table 1. Thirty selected areas of similar uplift rates and their values of morphometric indices.

Table 2. Fifteen selected catchments, their values of morphometric indices and their associated uplift rates.

\section{References}

Abdullah, C., Rampnoux, J.-P., Bellon, H., Maury, R., Soeria-Atmadja, R., 2000. The evolution of Sumba Island (Indonesia) revisited in the light of new data on the geochronology and geochemistry of the magmatic rocks. Journal of Asian Earth Sciences, 18(5), 533-546. doi:10.1016/S1367-9120(99)00082-6.

Ahnert, F., 1984. Local relief and the height limits of mountain ranges. Am J Sci 284, 10351055. doi:10.2475/ajs.284.9.1035

Audley-Charles, M., 1975. The Sumba fracture: A major discontinuity between eastern and western Indonesia. Tectonophysics, 26(3), 213-228. doi:10.1016/0040-1951(75)900918.

Audley-Charles, M.G., 2011. Tectonic post-collision processes in Timor. Geological Society, London, Special Publications 355, 241-266. doi:10.1144/SP355.12.

Bard, E., Jouannic, C., Hamelin, B., Pirazzoli, P., Arnold, M., Faure, G., Sumosusastro, P., 1996. Pleistocene sea levels and tectonic uplift based on dating of corals from Sumba Island, Indonesia. Geophysical Research Letters, 23(12), 1473-1476. doi: 10.1029/96GL01279 
Binnie, S.A., Phillips, W.M., Summerfield, M.A., Fifield, L.K., 2007. Tectonic uplift, threshold hillslopes, and denudation rates in a developing mountain range. Geology 35, 743-746. doi:10.1130/G23641A.

Bintanja, R., van de Wal, R.S., Oerlemans, J., 2005. Modelled atmospheric temperatures and global sea levels over the past million years. Nature 437, 125-128. doi:10.1038/nature03975

Brocklehurst, S.H., Whipple, K.X., 2004. Hypsometry of glaciated landscapes. Earth Surface Processes and Landforms 29, 907-926. doi:10.1002/esp.1083

Bull, W.B., McFadden, L.D., 1977. Tectonic geomorphology north and south of the Garlock fault, California. Geomorphology in arid regions 115-138.

Bullard, T.F., Lettis, W.R., 1993. Quaternary fold deformation associated with blind thrust faulting, Los Angeles Basin, California. Journal of Geophysical Research: Solid Earth (1978-2012), 98(B5), 8349-8369. doi:10.1029/93JB00012

Burbank, D.W., Leland, J., Fielding, E., Anderson, R.S., Brozovic, N., Reid, M.R., Duncan, C., 1996. Bedrock incision, rock uplift and threshold hillslopes in the northwestern Himalayas. Nature 379, 505-510. doi:10.1038/379505a0

Burbank, D., Anderson, R.S., 2012. Tectonic Geomorphology 2nd Edition. Wiley Blackwell. doi: 0.1002/9781444345063.refs

Castillo, M., Muñoz-Salinas, E., Ferrari, L., 2014. Response of a landscape to tectonics using channel steepness indices (ksn) and OSL: A case of study from the Jalisco Block, Western Mexico. Geomorphology 221, 204-214. doi:10.1016/j.geomorph.2014.06.017

Champagnac, J.-D., Valla, P.G., Herman, F., 2014. Late-Cenozoic relief evolution under evolving climate: A review. Tectonophysics 614, 44-65. doi:10.1016/j.tecto.2013.11.037

Chappell, J., 1974a. The geomorphology and evolution of small valleys in dated coral reef terraces, New Guinea. The Journal of Geology, 82(6), 795-812.

Chappell, J., 1974b. Geology of coral terraces, Huon Peninsula, New Guinea: A study of Quaternary tectonic movements and sea-level changes. Geological Society of America Bulletin, 85(4), 553-570. doi:10.1130/0016-7606(1974)85<553:GOCTHP>2.0.CO;2

Cheng, K.-Y., Hung, J.-H., Chang, H.-C., Tsai, H., Sung, Q.-C., 2012. Scale independence of basin hypsometry and steady state topography. Geomorphology, 171-172, 1-11. doi: 10.1016/j.geomorph.2012.04.022 
Crosby, B.T., Whipple, K.X., Gasparini, N.M., Wobus, C.W., 2007. Formation of fluvial hanging valleys: Theory and simulation. Journal of Geophysical Research, Earth Surface, 112(F3), F03S10, doi:10.1029/2006JF000566.

Darwin, C., 1842. On the structure and distribution of coral reefs. 278 p. Smith, Elder \& Co., London, England, UK.

Delunel, R., Van Der Beek, P. A., Carcaillet, J., Bourlès, D. L., Valla, P., G., 2010. Frostcracking control on catchment denudation rates: Insights from in situ produced 10Be concentrations in stream sediments (Ecrinx-Pelvoux massif, French Western Alps), 293, 72-83. doi:10.1016/j.epsl.2010.02.020

DiBiase, R.A., Whipple, K.X., Heimsath, A.M., Ouimet, W.B., 2010. Landscape form and millennial erosion rates in the San Gabriel Mountains, CA. Earth and Planetary Science Letters 289, 134-144. doi:10.1016/j.eps1.2009.10.036

Duvall, A., Kirby, E., Burbank, D., 2004. Tectonic and lithologic controls on bedrock channel profiles and processes in coastal California. Journal of Geophysical Research, 109(F3002), 1-18. doi:10.1029/2003JF000086

Effendi, A.C., Apandi, T., 1981. Geological map of Sumba quadrangle. Base compiled by the Geological Research Develop. Center United States Army Map Service Series SC 50-8.

Farr, T.G., Rosen, P.A., Caro, E., Crippen, R., Duren, R., Hensley, S., Kobrick, M., Paller, M., Rodriguez, E., Roth, L., Seal1, D., Shaffer, S., Shimada, J., Umland, J., Werner, M., Oskin, M., Burbank, D., Alsdorf, D., 2007. The shuttle radar topography mission. Reviews of geophysics 45. doi:10.1029/2005RG000183

Flint, J.J., 1974. Stream gradient as a function of order, magnitude, and discharge. Water Resources Research 10, 969-973.

Fleury, J.-M., Pubellier, M., de Urreiztieta, M., 2009. Structural expression of forearc crust uplift due to subducting asperity. Lithos, 113(1), 318-330. doi: 10.1016/j.lithos.2009.07.007

Fortuin, A.R., Van der Werff, W., Wensink, H., 1997. Neogene basin history and paleomagnetism of a rifted and inverted forearc region, on-and offshore Sumba, Eastern Indonesia. Journal of Asian Earth Sciences 15, 61-88. doi: 10.1016/S07439547(96)00081-5

Hack, J.T., 1957. Studies of Longitudinal Stream Profiles in Virginia and Maryland (Geological Survey Professional Paper No. 294-B), Shorter Contributions to General Geology. 
Hack, J.T., 1973. Stream-profile analysis and stream-gradient index. Journal of Research of the US Geological Survey, 1(4), 421-429.

Haghipour, N., Burg, J.-P., 2014. Geomorphological analysis of the drainage system on the growing Makran accretionary wedge. Geomorphology 209, 111-132. doi:10.1016/j.geomorph.2013.11.030

Haig, D.W., 2012. Palaeobathymetric gradients across Timor during 5.7-3.3 Ma (latest Miocene-Pliocene) and implications for collision uplift. Palaeogeography, Palaeoclimatology, Palaeoecology 331-332, 50-59,. doi:10.1016/j.palaeo.2012.02.032

Hall, R., 2002. Cenozoic geological and plate tectonic evolution of SE Asia and the SW Pacific: computer-based reconstructions, model and animations. Journal of Asian Earth Sciences, 20(4), 353-431, doi: 10.1016/S1367-9120(01)00069-4

Hall, R., Smyth, H.R., 2008. Cenozoic arc processes in Indonesia: Identification of the key influences on the stratigraphic record in active volcanic arcs, in: Special Paper 436: Formation and Applications of the Sedimentary Record in Arc Collision Zones. Geological Society of America, pp. 27-54.

Hall, R., Sevastjanova, I., 2012. Australian crust in Indonesia. Australian Journal of Earth Sciences 59, 827-844, doi:10.1080/08120099.2012.692335

Hantoro, W., 1992. Etude des terrasses récifales quaternaires soulevées entre le détroit de la Sonde et l'île de Timor, Indonésie. Mouvements Verticaux de la Croûte terrestre et variations du niveau de la mer, PhD Thesis Univ. d'Aix Marseille II. France.

Harris, R., Vorkink, M.W., Prasetyadi, C., Zobell, E., Roosmawati, N., Apthorpe, M., 2009. Transition from subduction to arc-continent collision: Geologic and neotectonic evolution of Savu Island, Indonesia. Geosphere, 5(3), 152-171, doi:10.1130/GES00209.1

Harris, R., 2011. The Nature of the Banda Arc-Continent Collision in the Timor Region, in: Arc-Continent Collision, Frontiers in Earth Sciences. Springer Berlin Heidelberg, pp. 163-211, doi: 10.1007/978-3-540-88558-0_7

Hilley, G.E., Arrowsmith, J.R., 2008. Geomorphic response to uplift along the Dragon's Back pressure ridge, Carrizo Plain, California. Geology, 36(5), 367-370, doi: 10.1130/G24517A.1

Hinschberger, F., Malod, J.-A., Réhault, J.-P., Villeneuve, M., Royer, J.-Y., Burhanuddin, S., 2005. Late Cenozoic geodynamic evolution of eastern Indonesia. Tectonophysics, 404(1), 91-118, doi:10.1016/j.tecto.2005.05.005 
Jouannic, C., Hantoro, W. S., Hoang, C. T., Fournier, M., Lafon, R., Ichram, M.L., 1988. Quaternary raised reef terraces at Cape Laundi, Sumba, Indonesia: Geomrphological analysis and first radiometric ( $\mathrm{Th} / \mathrm{U}$ and $14 \mathrm{C})$ age determinations. Presented at the Processing of the 6th International Coral Reef Symposium, Townsville, Australia, pp. $441-447$.

Kale, V.S., Shejwalkar, N., 2008. Uplift along the western margin of the Deccan Basalt Province: Is there any geomorphometric evidence? Journal of earth system science 117 , 959-971.

Keep, M., Haig, D.W., 2010. Deformation and exhumation in Timor: Distinct stages of a young orogeny. Tectonophysics, Convergent plate margin dynamics: New perspectives from structural geology, geophysics and geodynamic modelling 483, 93-111. doi:10.1016/j.tecto.2009.11.018

Keller, E.A., Pinter, N., 2000. Active tectonics: Earthquakes, uplift, and landscape. Prentice Hall, Upper Saddle River.

Kirby, E., Whipple, K.X., 2012. Expression of active tectonics in erosional landscapes. Journal of Structural Geology 44, 54-75. doi:10.1016/j.jsg.2012.07.009

Kottek, M., Grieser, J., Beck, C., Rudolf, B., Rubel, F., 2006. World map of the KoppenGeiger climate classification updated. Meteorologische Zeitschrift, 15(3), 259-264. doi: $10.1127 / 0941-2948 / 2006 / 0130$

Lambeck, K., Yokoyama, Y., Purcell, T., 2002. Into and out of the Last Glacial Maximum: sea-level change during Oxygen Isotope Stages 3 and 2. Quaternary Science Reviews $21,343-360$.

Lifton, N.A., Chase, C.G., 1992. Tectonic, climatic and lithologic influences on landscape fractal dimension and hypsometry: implications for landscape evolution in the San Gabriel Mountains, California. Geomorphology 5, 77-114. doi:10.1016/0169$555 \mathrm{X}(92) 90059-\mathrm{W}$

Lyell, C., 1851. Elements of Geology. Smith and Peters.

Lytwyn, J., Rutherford, E., Burke, K., Xia, C., 2001. The geochemistry of volcanic, plutonic and turbiditic rocks from Sumba, Indonesia. Journal of Asian Earth Sciences, 19(4), 481-500. doi:10.1016/S1367-9120(00)00031-6

Maroukian, H., Gaki-Papanastassiou, K., Karymbalis, E., Vouvalidis, K., Pavlopoulos, K., Papanastassiou, D., Albanakis, K., 2008. Morphotectonic control on drainage network evolution in the Perachora Peninsula, Greece. Geomorphology 102, 81-92. doi: 10.1016/j.geomorph.2007.07.021 
Mayer, L., 1990. Introduction to quantitative geomorphology: an exercise manual. PrenticeHall International, Inc.

Merritts, D., Vincent, K.R., 1989. Geomorphic response of coastal streams to low, intermediate, and high rates of uplift, Medocino triple junction region, northern California. Geological Society of America Bulletin, 101, 1373-1388. doi:10.1130/00167606(1989)101<1373:GROCST>2.3.CO;2

Miller, S.R., Sak, P.B., Kirby, E., Bierman, P.R., 2013. Neogene rejuvenation of central Appalachian topography: Evidence for differential rock uplift from stream profiles and erosion rates. Earth and Planetary Science Letters 369-370, 1-12. doi:10.1016/j.eps1.2013.04.007

Montgomery, D.R., Brandon, M.T., 2002. Topographic controls on erosion rates in tectonically active mountain ranges. Earth and Planetary Science Letters 201, 481-489. doi:10.1016/S0012-821X(02)00725-2

Montaggioni, L.F., Braithwaite, C.J., 2009. Quaternary coral reef systems: history, development processes and controlling factors, 5 .

Ouimet, W.B., Whipple, K.X., Granger, D.E., 2009. Beyond threshold hillslopes: Channel adjustment to base-level fall in tectonically active mountain ranges. Geology 37, 579582. doi:10.1130/G30013A.1

Pedoja, K., Husson, L., Regard, V., Cobbold, P.R., Ostanciaux, E., Johnson, M.E., Kershaw, S., Saillard, M., Martinod, J., Furgerot, L., 2011. Relative sea-level fall since the last interglacial stage: Are coasts uplifting worldwide? Earth-Science Reviews, 108(1), 115, doi:10.1016/j.earscirev.2011.05.002

Pedoja, K., Husson, L., Johnson, M.E., Melnick, D., Nexer, M., Witt, C., Pochat, S., Authemayou, C., Delcaillau, B., Regard, V., Poprawski, Y., 2014. Coastal staircase sequences reflecting sea-level oscillations and tectonic uplift during the Quaternary and Neogene. Earth Science Review, 132, 13-38, doi:10.1016/j.earscirev.2014.01.007

Perron, J.T., Royden, L., 2012. An integral approach to bedrock river profile analysis. Earth Surface Processes and Landforms, 38(6), 570-576. doi:10.1038/nature11672

Pirazzoli, P., Radtke, U., Hantoro, W., Jouannic, C., Hoang, C., Causse, C., Best, M.B., 1991. Quaternary raised coral-reef terraces on Sumba Island, Indonesia. Science, 252(5014), 1834-1836. doi:10.1126/science.252.5014.1834

Pirazzoli, P., Radtke, U., Hantoro, W., Jouannic, C., Hoang, C., Causse, C., Best, M.B., 1993. A one million-year-long sequence of marine terraces on Sumba Island, Indonesia. Marine Geology, 109(3), 221-236. doi:10.1016/0025-3227(93)90062-Z 
Pirazzoli, P.A., 2005. Sea-level indicators, geomorphic, Encyclopedia of Coastal Science. Springer, 836-838.

Roe, G.H., Montgomery, D.R., Halley, B., 2003. Orographic precipitation and the relief of mountain ranges. Journal of Geophysical Research, 108, 2315. doi:10.1130/00917613(2002)030<0143:EOOPVO>2.0.CO;2

Rutherford, E., Burke, K., Lytwyn, J., 2001. Tectonic history of Sumba Island, Indonesia, since the Late Cretaceous and its rapid escape into the forearc in the Miocene. Journal of Asian Earth Sciences, 19(4), doi:453-479. 10.1016/S1367-9120(00)00032-8

Scherler, D., Bookhagen, B., Strecker, M.R., 2014. Tectonic control on 10Be-derived erosion rates in the Garhwal Himalaya, India. Journal of Geophysical Research: Earth Surface 119, 83-105, doi:10.1002/2013JF002955

Schildgen, T.F., Cosentino, D., Bookhagen, B., Niedermann, S., Yildirim, C., Echtler, H.P., Wittmann, H., Strecker, M.R., 2012. Multi-phase uplift of the southern margin of the Central Anatolian plateau: A record of tectonic and upper mantle processes. Earth and Planetary Science Letters, 317-318, 85-95, doi:10.1016/j.epsl.2011.12.003

Siddall, M., Chappell, J., Potter, E.-K., 2006. 7. Eustatic sea level during past interglacials. Developments in Quaternary Sciences, 7, 75-92, doi:10.1016/S1571-0866(07)80032-7

Shulgin, A., Kopp, H., Mueller, C., Lueschen, E., Planert, L., Engels, M., Flueh, E.R., Krabbenhöft, A., Djajadihardja, Y., 2009. Sunda-Banda arc transition: Incipient continent-island arc collision (northwest Australia). Geophysical Research Letters, 36(10), L10304.

Smith, W.H., Sandwell, D.T., 1997. Global sea floor topography from satellite altimetry and ship depth soundings. Science 277, 1956-1962.

Snyder, N.P., Whipple, K.X., Tucker, G.E., Merritts, D.J., 2000. Landscape response to tectonic forcing: Digital elevation model analysis of stream profiles in the Mendocino triple junction region, northern California. Geological Society of America Bulletin, 112(8), 1250-1263, doi:10.1130/0016-7606(2000)112<1250:LRTTFD>2.0.CO;2

Snyder, N.P., Whipple, K.X., Tucker, G.E., Merritts, D.J., 2002. Interactions between onshore bedrock-channel incision and nearshore wave-base erosion forced by eustasy and tectonics. Basin Research 14, 105-127, doi:10.1046/j.1365-2117.2002.00169.x

Stearns, R.G., 1967. Warping of the Western Highland Rim Peneplain in Tennessee by ground-water sapping. Geological Society of America Bulletin, 78(9), 1111-1124, doi:10.1130/0016-7606(1967)78[1111:WOTWHR]2.0.CO;2 
Strahler, A.N., 1952. Hypsometric (area-altitude) analysis of erosional topography. Geological Society of America Bulletin, 63, 1117-1142, doi:10.1130/00167606(1952)63[1117:HAAOET]2.0.CO;2

Strahler, A.N., 1957. Quantitative analysis of watershed geomorphology. Transactions of the American Geophysical Union, 38(6), 913-920, doi:10.1029/TR038i006p00913

Tucker, G.E., Bras, R.L., 1998. Hillslope processes, drainage density, and landscape morphology. Water Resources Research, 34(10), 2751-2764, doi:10.1029/98WR01474

Tucker, G.E., Whipple, K.X., 2002. Topographic outcomes predicted by stream erosion models: Sensitivity analysis and intermodel comparison. J. Geophys. Res. 107, 2179. doi:10.1029/2001JB000162

Von Blanckenburg, F., 2005. The control mechanisms of erosion and weathering at basin scale from cosmogenic nuclides in river sediment. Earth and Planetary Science Letters 237, 462-479. doi:10.1016/j.epsl.2005.06.030

Whipple, K.X., Tucker, G.E., 1999. Dynamics of the stream-power river incision model: Implications for height limits of mountain ranges, landscape response timescales, and research needs. Journal of Geophysical Research, 104(B8), 17661-17674, doi:10.1029/1999JB900120

Whipple, K.X., 2001. Fluvial Landscape Response Time: How Plausible Is Steady-State Denudation? Am J Sci 301, 313-325. doi:10.2475/ajs.301.4-5.313

Whipple, K.X., 2009. The influence of climate on the tectonic evolution of mountain belts. Nature Geoscience, 2, 97-104, doi:10.1038/ngeo413

Willgoose, G., Hancock, G., 1998. Revisiting the hypsometric curve as an indicator of form and process in transport-limited catchment. Earth Surface Processes and Landforms, 23(7), 611-623, doi:10.1002/(SICI)1096-9837(199807)23:7<611::AIDESP872>3.0.CO;2-Y

Wobus, C., Whipple, K.X., Kirby, E., Snyder, N., Johnson, J., Spyropolou, K., Crosby, B., Sheehan, D., 2006a. Tectonics from topography: Procedures, promise, and pitfalls. Special Papers Geological Society of America, 398, 55-74, doi:10.1130/2006.2398(04)

Wobus, C.W., Crosby, B.T., Whipple, K. X., 2006b. Hanging valleys in fluvial systems: Controls on occurrence and implications for landscape evolution. Journal fo Geophysical research, Earth Surface, 11(F2), doi:10.1029/2005JF000406.

Wobus, C.W., Tucker, G.E., Anderson, R.S., 2006c. Self-formed bedrock channels. Geophysical Research Letters, 33 (L18408), doi:10.1029/2006GL027182 
Yildirim, C., Schildgen, T.F., Echtler, H., Melnick, D., Strecker, M.R., 2011. Late Neogene and active orogenic uplift in the Central Pontides associated with the North Anatolian Fault: Implications for the northern margin of the Central Anatolian Plateau, Turkey. Tectonics, 30(5), TC5005, doi:10.1029/2010TC002756 


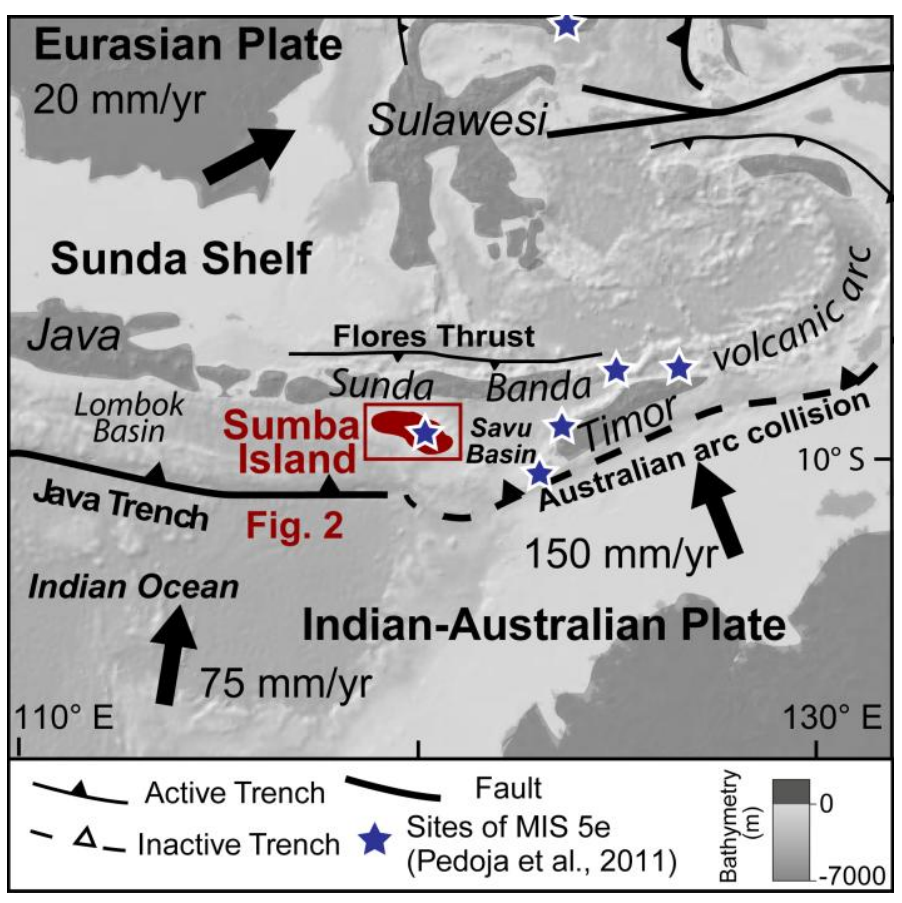

Figure 1 


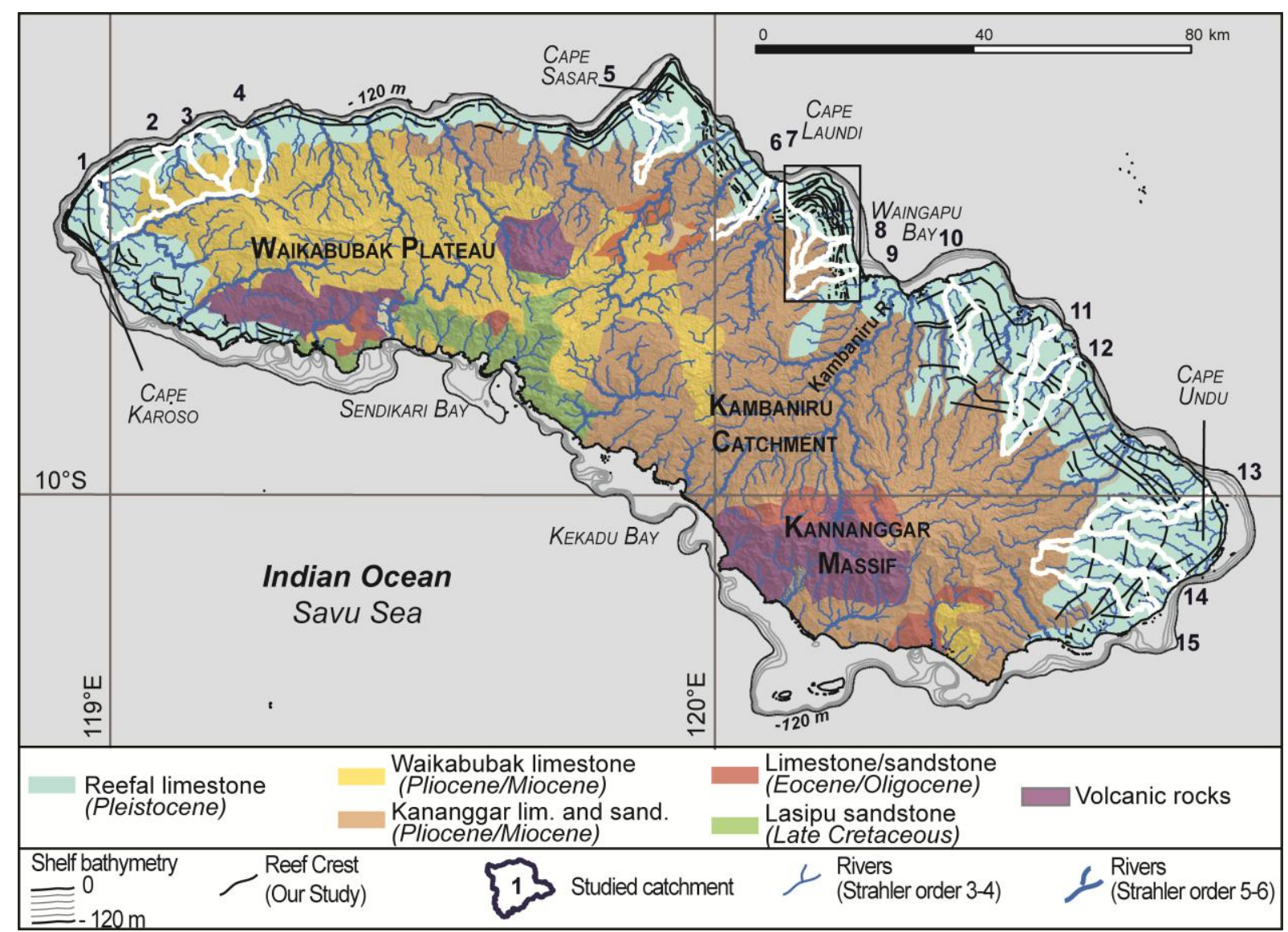

Figure 2 


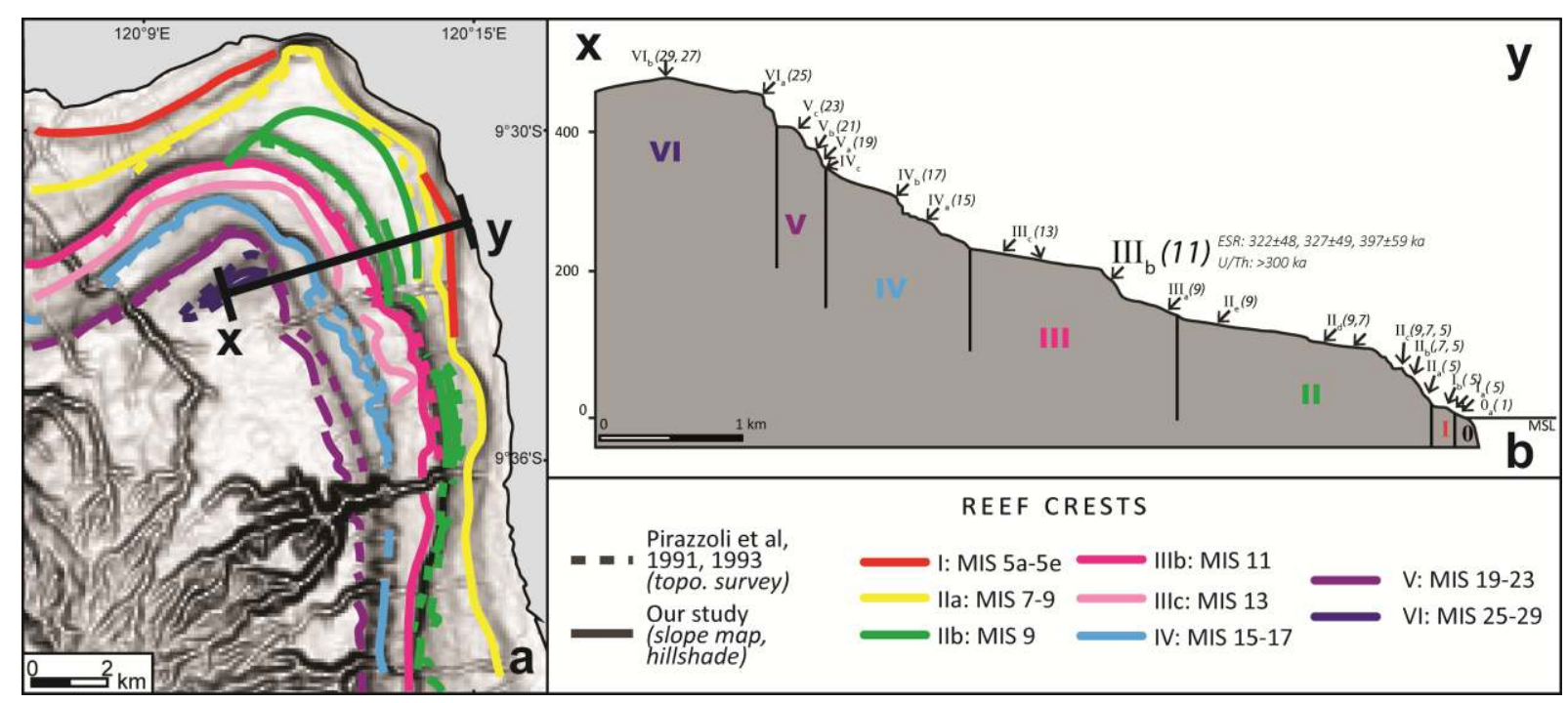

Figure 3 

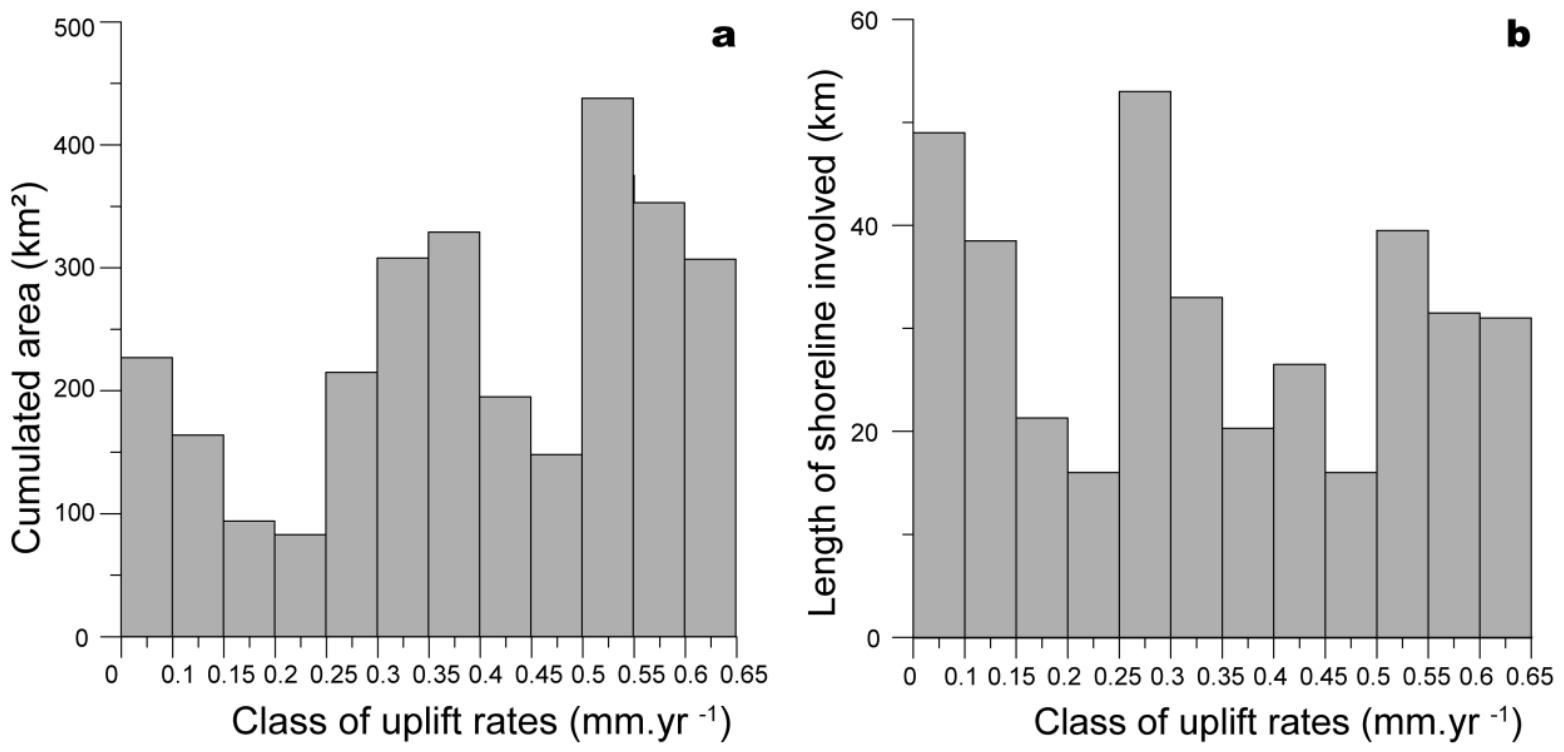

Figure 4 


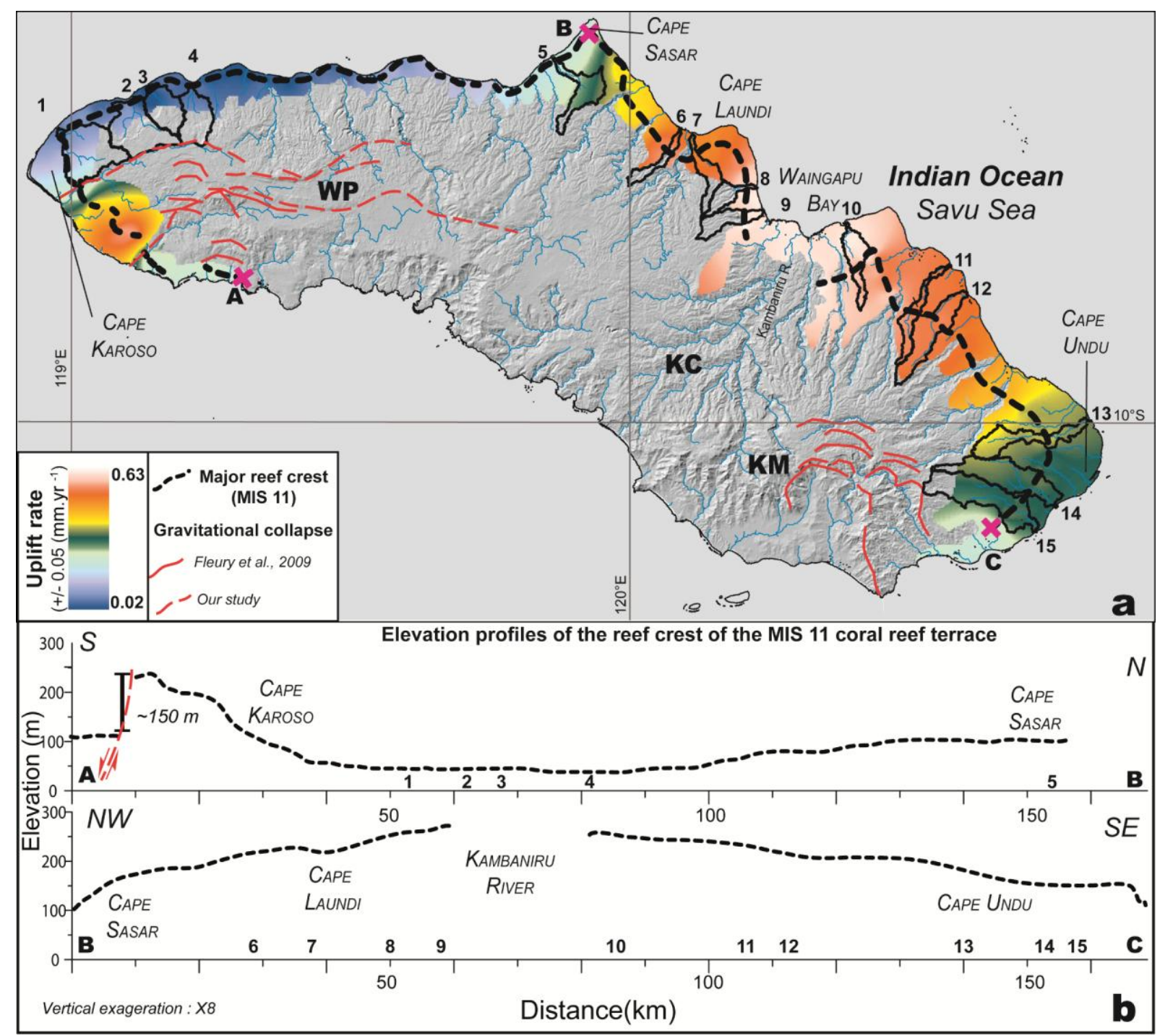

Figure 5 


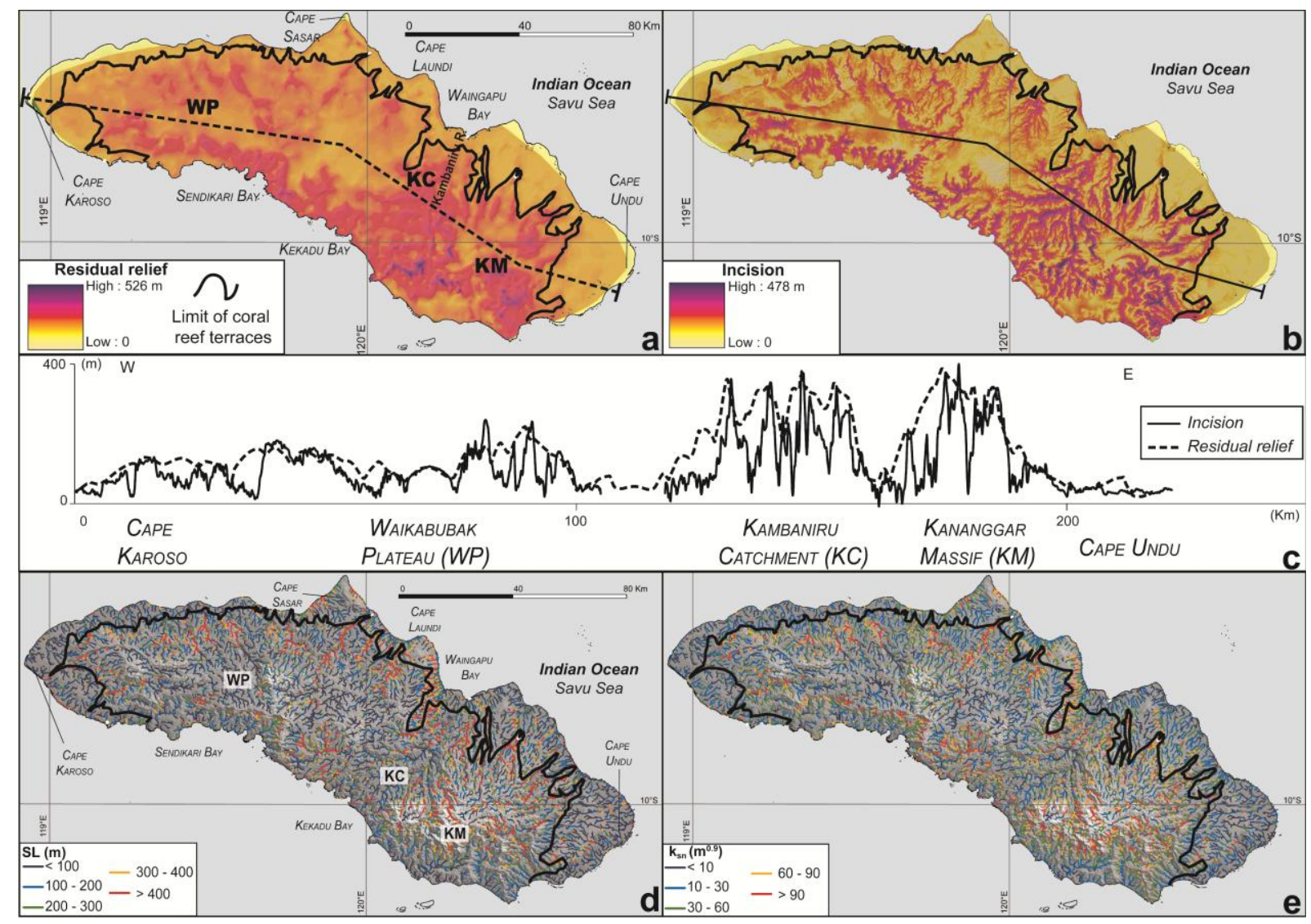

Figure 6 


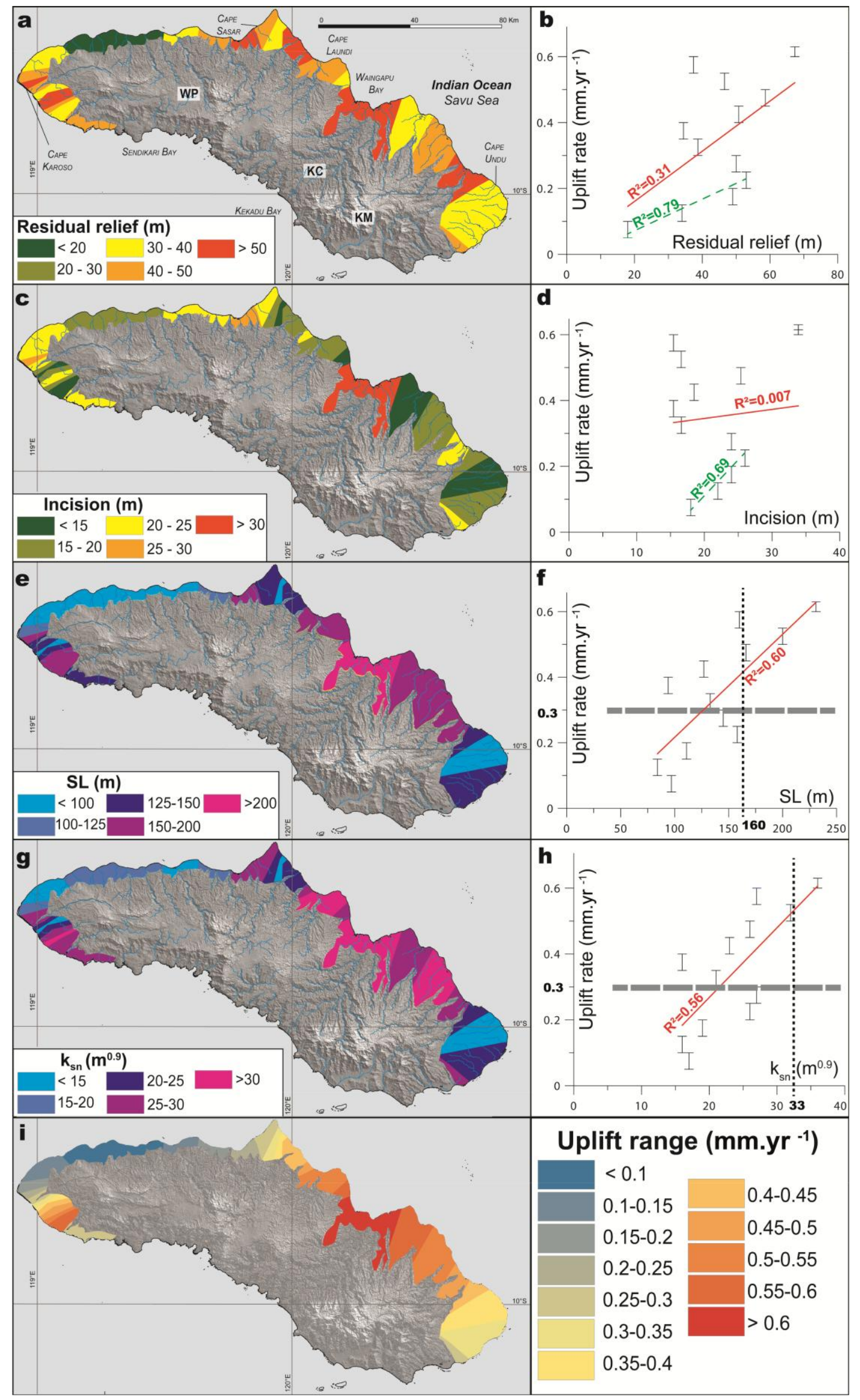

Figure 7 


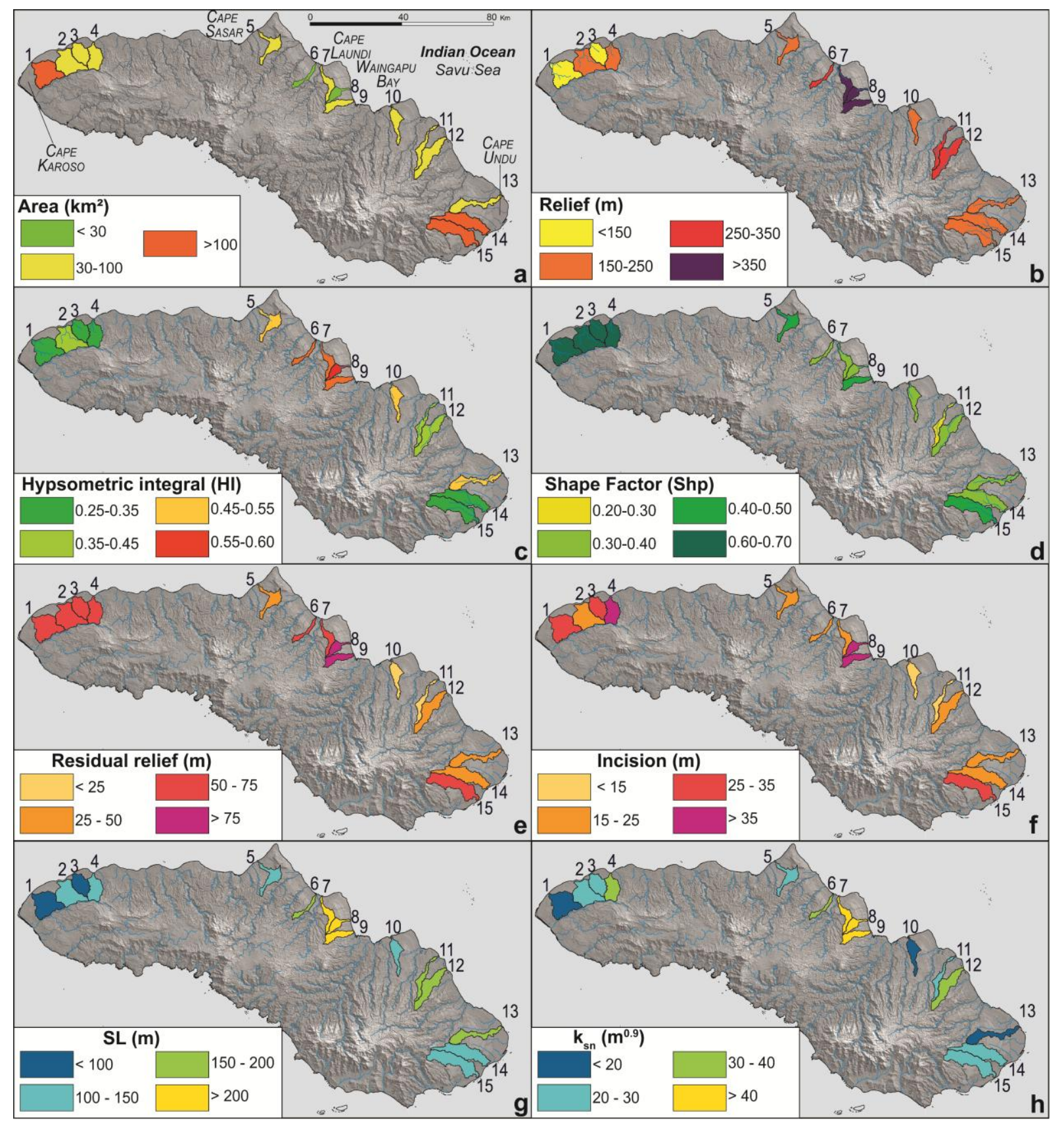

Figure 8 

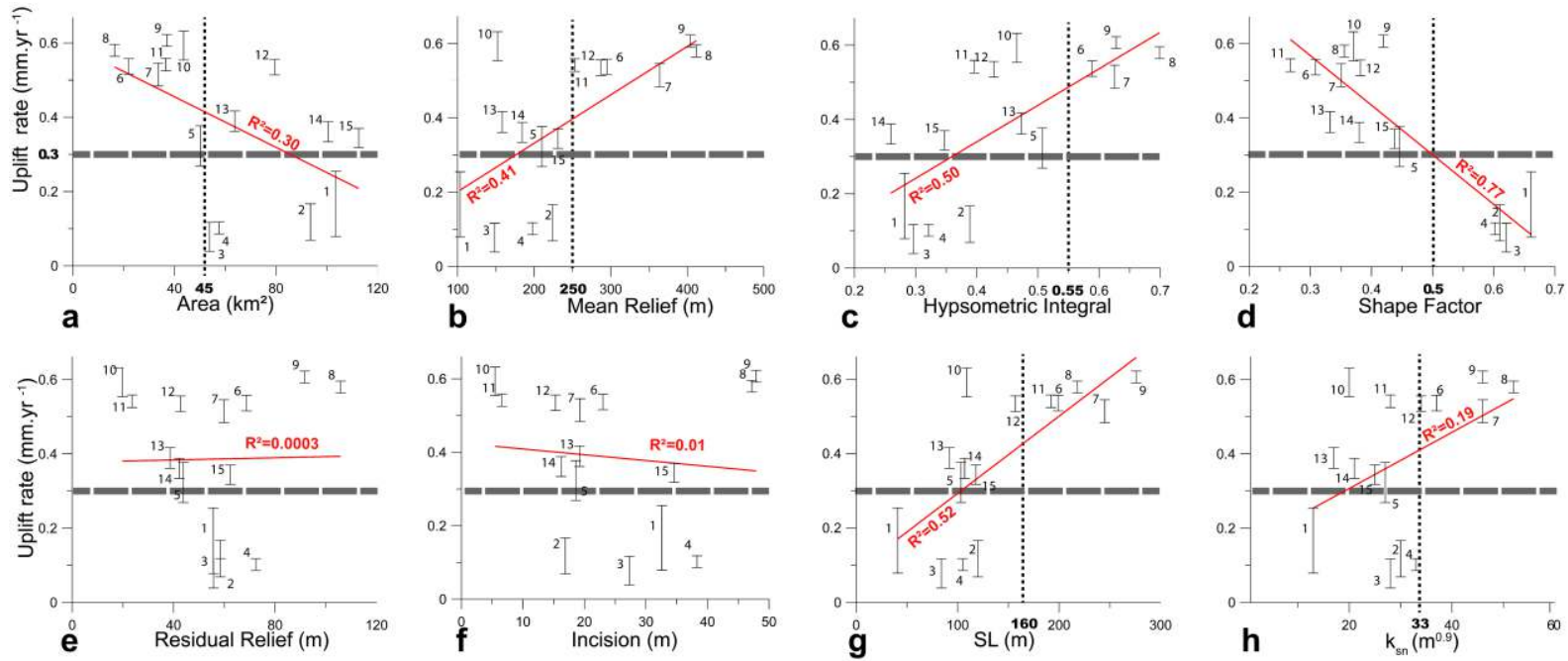

Figure 9 

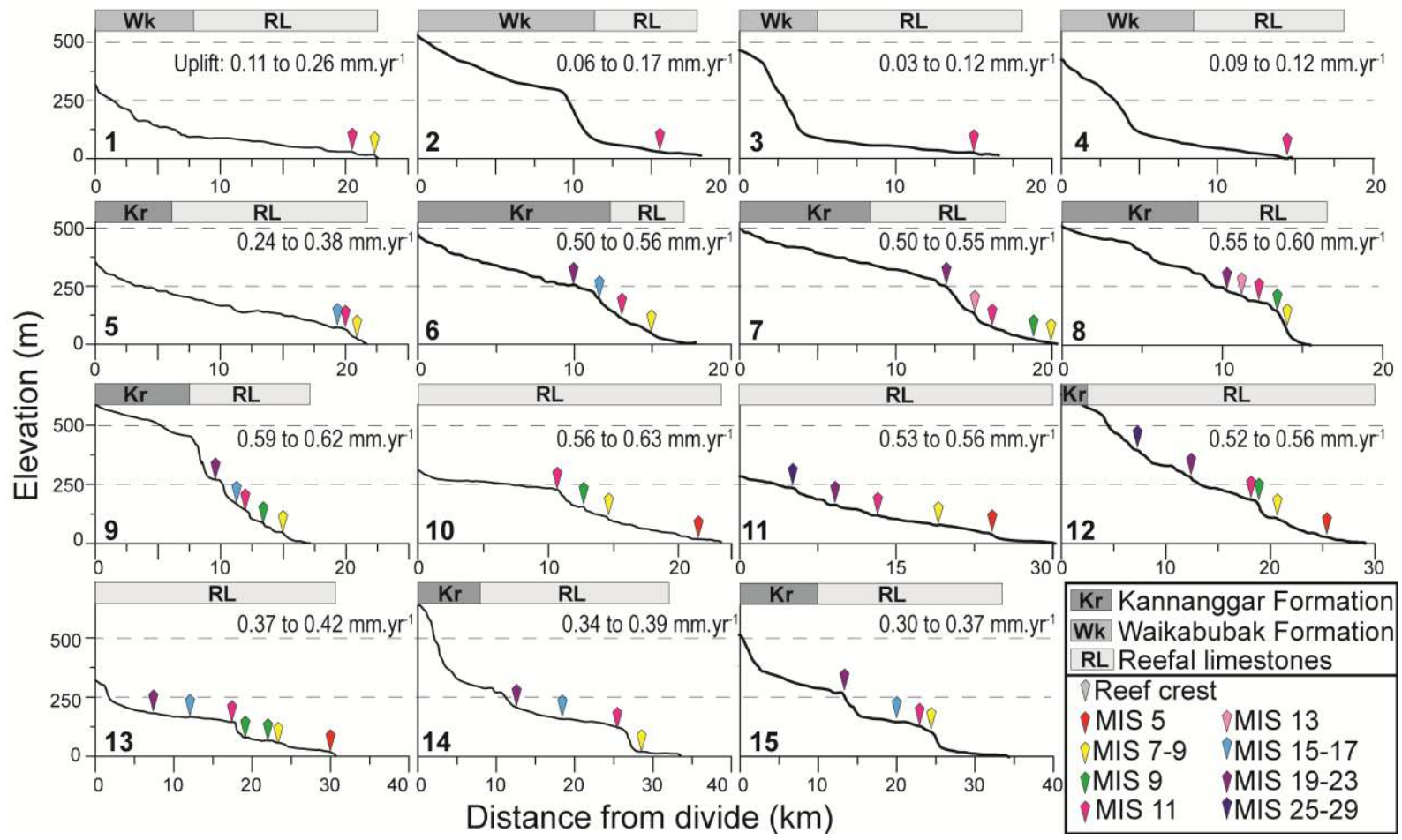

Figure 10 
Table 1

\begin{tabular}{|c|c|c|c|c|c|}
\hline Zones of similar uplift (mm/yr) & Area $(\mathrm{km} 2)$ & Zones of similar uplift (mm/yr) & \multicolumn{3}{|c|}{ Incision (m) } \\
\hline & & & mean & $\min$ & $\max$ \\
\hline$<0,1$ & 228 & $<0,1$ & 18 & 0 & 134 \\
\hline $0,1-0,15$ & 51 & $0,1-0,15$ & 25 & 0 & 105 \\
\hline $0,1-0,15$ & 114 & $0,1-0,15$ & 25 & 0 & 105 \\
\hline Sum of zones $(0,1-0,15 \mathrm{~mm} / \mathrm{yr})$ & 165 & Mean of zones $(0,1-0,15 \mathrm{~mm} / \mathrm{yr})$ & 25 & 0 & 105 \\
\hline $0,15-0,2$ & 43 & $0,15-0,2$ & 25 & 0 & 117 \\
\hline $0,15-0,2$ & 51 & $0,15-0,2$ & 24 & 0 & 78 \\
\hline Sum of zones $(0,15-0,2 \mathrm{~mm} / \mathrm{yr})$ & 94 & Mean of zones $(0,15-0,2 \mathrm{~mm} / \mathrm{yr})$ & 25 & 0 & 97 \\
\hline $0,2-0,25$ & 57 & $0,2-0,25$ & 27 & 0 & 109 \\
\hline $0,2-0,25$ & 26 & $0,2-0,25$ & 24 & 0 & 75 \\
\hline Sum of zones $(0,2-0,25 \mathrm{~mm} / \mathrm{yr})$ & 83 & Mean of zones $(0,2-0,25 \mathrm{~mm} / \mathrm{yr})$ & 26 & 0 & 92 \\
\hline $0,25-0,3$ & 75 & $0,25-0,3$ & 26 & 0 & 150 \\
\hline $0,25-0,3$ & 44 & $0,25-0,3$ & 22 & 0 & 80 \\
\hline $0,25-0,3$ & 74 & $0,25-0,3$ & 18 & 0 & 95 \\
\hline $0,25-0,3$ & 22 & $0,25-0,3$ & 41 & 0 & 94 \\
\hline Sum of zones $(0,25-0,3 \mathrm{~mm} / \mathrm{yr})$ & 215 & Mean of zones $(0,25-0,3 \mathrm{~mm} / \mathrm{yr})$ & 27 & 0 & 105 \\
\hline $0,3-0,35$ & List & $0,3-0,35$ & 19 & 0 & 96 \\
\hline $0,3-0,35$ & 19 & $0,3-0,35$ & 42 & 0 & 102 \\
\hline $0,3-0,35$ & 239 & $0,3-0,35$ & 14 & 0 & 97 \\
\hline Sum of zones $(0,3-0,35 \mathrm{~mm} / \mathrm{yr})$ & 258 & Mean of zones $(0,3-0,35 \mathrm{~mm} / \mathrm{yr})$ & 25 & 0 & 98 \\
\hline $0,35-0,4$ & 280 & $0,35-0,4$ & 13 & 0 & 89 \\
\hline $0,35-0,4$ & 22 & $0,35-0,4$ & 49 & 0 & 91 \\
\hline $0,35-0,4$ & 28 & $0,35-0,4$ & 9 & 0 & 88 \\
\hline Sum of zones $(0,35-0,4 \mathrm{~mm} / \mathrm{yr})$ & 330 & Mean of zones $(0,35-0,4 \mathrm{~mm} / \mathrm{yr})$ & 24 & 0 & 89 \\
\hline $0,4-0,45$ & 80 & $0,4-0,45$ & 14 & 0 & 132 \\
\hline $0,4-0,45$ & 35 & $0,4-0,45$ & 43 & 0 & 122 \\
\hline $0,4-0,45$ & 79 & $0,4-0,45$ & 14 & 0 & 116 \\
\hline Sum of zones $(0,4-0,45 \mathrm{~mm} / \mathrm{yr})$ & 194 & Mean of zones $(0,4-0,45 \mathrm{~mm} / \mathrm{yr})$ & 24 & 0 & 123 \\
\hline $0,45-0,5$ & 41 & $0,45-0,5$ & 35 & 0 & 122 \\
\hline $0,45-0,5$ & 89 & $0,45-0,5$ & 24 & 0 & 221 \\
\hline $0,45-0,5$ & 20 & $0,45-0,5$ & 15 & 0 & 99 \\
\hline Sum of zones $(0,45-0,5 \mathrm{~mm} / \mathrm{yr})$ & 150 & Mean of zones $(0,45-0,5 \mathrm{~mm} / \mathrm{yr})$ & 25 & 0 & 147 \\
\hline $0,5-0,55$ & 142 & $0,5-0,55$ & 15 & 0 & 110 \\
\hline $0,5-0,55$ & 271 & $0,5-0,55$ & 17 & 0 & 273 \\
\hline $0,5-0,55$ & 24 & $0,5-0,55$ & 20 & 0 & 95 \\
\hline Sum of zones $(0,5-0,55 \mathrm{~mm} / \mathrm{yr})$ & 437 & Mean of zones $(0,5-0,55 \mathrm{~mm} / \mathrm{yr})$ & 17 & 0 & 159 \\
\hline $0,55-0,6$ & 60 & $0,55-0,6$ & 16 & 0 & 63 \\
\hline $0,55-0,6$ & 33 & $0,55-0,6$ & 43 & 0 & 166 \\
\hline $0,55-0,6$ & 261 & $0,55-0,6$ & 12 & 0 & 139 \\
\hline Sum of zones $(0,55-0,6 \mathrm{~mm} / \mathrm{yr})$ & 354 & Mean of zones $(0,55-0,6 \mathrm{~mm} / \mathrm{yr})$ & 24 & 0 & 123 \\
\hline$>0,6$ & 308 & $>0,6$ & 34 & 0 & 178 \\
\hline
\end{tabular}


Table 2

\begin{tabular}{|c|c|c|c|c|c|c|c|}
\hline Catch. & Area $\left(\mathrm{km}^{2}\right)$ & Relief国m) & HI & Shp factor & Res. Relief (im) & Incision兯m) & S녕m) \\
\hline 1 & 104 & 103 & 0.28 & 0.66 & 56 & \begin{tabular}{r|}
33 \\
\end{tabular} & 41 \\
\hline 2 & 94 & 224 & 0.39 & 0.61 & 58 & 17 & 120 \\
\hline 3 & 54 & 148 & 0.30 & 0.62 & 56 & 27 & 84 \\
\hline 4 & 58 & 198 & 0.32 & 0.60 & 72 & 38 & 105 \\
\hline 5 & 50 & 210 & 0.51 & 0.45 & 44 & 19 & 103.3 \\
\hline 6 & 22 & 295 & 0.59 & 0.31 & 69 & 23 & 199 \\
\hline 7 & 34 & 364 & 0.63 & 0.35 & 60 & 19 & 245 \\
\hline 8 & 16 & 412 & 0.70 & 0.36 & 106 & 47 & 218 \\
\hline 9 & 37 & 404 & 0.63 & 0.42 & 92 & 48 & 276 \\
\hline 10 & 44 & 152 & 0.47 & 0.37 & 20 & 5 & 109 \\
\hline 11 & 37 & 253 & 0.40 & 0.27 & 24 & 7 & 192 \\
\hline 12 & 79 & 287 & 0.43 & 0.38 & 43 & 15 & 157 \\
\hline 13 & 64 & 158 & 0.47 & 0.33 & 39 & 19 & 92 \\
\hline 14 & 101 & 184 & 0.26 & 0.38 & 42 & 16 & 107 \\
\hline 15 & 113 & 231 & 0.35 & 0.44 & 62 & 35 & 118 \\
\hline
\end{tabular}

